UNIVERSIDADE DE BRASÍLIA

Centro de Excelência em Turismo

Pós-graduação Lato Sensu

Curso de Especialização em Gastronomia e Segurança Alimentar III

\title{
ESTUDO DE CASO : \\ O EVENTO “ESTRELAS DA \\ GASTRONOMIA BRASILEIRA" \\ NO CHILE E A \\ VALORIZAÇÃO DA GASTRONOMIA \\ BRASILEIRA NO EXTERIOR
}

Sara Elisabeth Xavier Agra

Prof. Dra. Wilma Araújo

Brasília - 2009 


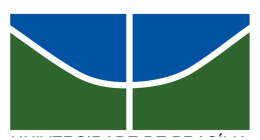

UNIVERSIDADE DE BRASÍLIA

Centro de Excelência em Turismo

Pós-graduação Lato Sensu

Curso de Especialização em Gastronomia e Segurança Alimentar III

\section{ESTUDO DE CASO :}

\section{O EVENTO "ESTRELAS DA}

\section{GASTRONOMIA BRASILEIRA"}

\section{NO CHILE E A \\ VALORIZAÇÃO DA GASTRONOMIA BRASILEIRA NO EXTERIOR}

Sara Elisabeth Xavier Agra

Prof. Dra. Wilma Araújo

Monografia apresentada ao Centro de Excelência em Turismo - CET, da Universidade de Brasília UnB, como requisito parcial à obtenção do grau de Especialista em Gastronomia e Segurança Alimentar III. 


Agra, Sara Elisabeth Xavier.
A gastronomia como atrativo cultural no subsistema turistico. Estudo de caso: O Evento Estrelas
da Gastronomia no Chile integrante do Projeto Movimento de Valorização da Gastronomia
Brasileira no Exterior
Universidade de Brasília UnB, Centro de Excelência em Turismo,2009.
Orientadora: Prof ${ }^{a}$ Dr $^{\text {a }}$ Wilma Araújo.
Monografia para pós - graduação em Gastronomia e Segurança Alimentar III.
1. gastronomia como atrativo cultural
2. $\quad$ subsistema turistico de mercado e o atrativo cultural
3. marketing: ferramentas de comunicação e promoção
4. evento
CDDl




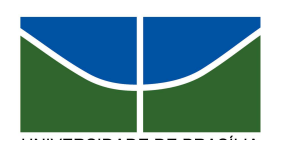

UNIVERSIDADE DE BRASÍLIA

Centro de Excelência em Turismo

Pós-graduação Lato Sensu

Curso de Especialização em Gastronomia e Segurança Alimentar III

Sara Elisabeth Xavier Agra

Aprovado por:

Professor orientador: Prof $^{a} \operatorname{Dr}^{a}$ Wilma Araújo

Professora Carla Tenser

Professora Ana Rosa Santos

Brasília, 27 de julho de 2009. 


\section{DEDICATÓRIA}

A DEUS, por sua presença constante em minha vida.

Aos meus pais Bertolino da Costa Agra e Otília Xavier Agra - in memória.

Ao meu filho Eduardo pedindo perdão por não podermos ficar juntos neste tempo..

A minha filha Juliana pela super estalagem em seus espaços.

À Professora Doutora Wilma Araújo orientadora desta monografia. 


\section{AGRADECIMENTOS}

À EMBRATUR- Instituto Brasileiro de Turismo, por ter proporcionado a minha participação no Curso de Gastronomia e Segurança Alimentar III;

Aos Diretores da EMBRATUR por autorizarem todos os meios legais para a conclusão desta monografia com sucesso;

Aos meus Pastores Wagner e Juliana Pangoni por suas orações;

A amiga Janice Amparo Castellar por suas indicações bibliográficas. 
Eu sou o pão da vida; o que vem a mim jamais terá fome; e o que crê em mim jamais terá sede.

João 6:35. 


\section{RESUMO}

AGRA, Sara Elisabeth Xavier. Estudo de caso: Evento Estrelas da Gastronomia no Chile Projeto Movimento de Valorização da Gastronomia Brasileira no Exterior. 2009. 65 páginas. Monografia - Programa de Pós-Graduação em Gastronomia e Segurança Alimentar III, Centro de Excelência em Turismo - UnB; Brasília, 2009.

O presente trabalho é um Estudo de Caso e tem como tema a promoção do turismo brasileiro no exterior por meio da divulgação da gastronomia típica do país. Seu objetivo é estudar a gastronomia como atrativo cultural no subsistema turístico do mercado e ferramenta promocional no plano de marketing internacional da EMBRATUR, com vistas a avaliar as estratégias do marketing promocional voltadas para captação de turismo internacional, definidos no "Projeto Movimento de Valorização da Gastronomia Brasileira no Exterior", em especial no evento "Estrelas da Gastronomia Brasileira", realizado em Santiago do Chile. O estudo consiste numa avaliação das ações previstas no plano de marketing promocional do referido evento, verificando se o retorno pretendido no projeto básico e a forma de mensuração dos resultados foram satisfatórios. Os resultados mostram que o evento foi muito importante e que, de fato, contribui para a propagação do turismo brasileiro, apesar de algumas incongruências e da inexistência de ferramentas precisas de mensuração do resultado a ser alcançado.

Palavras-chave: turismo, cultura, gastronomia, marketing, promoção, captação. 


\begin{abstract}
This work is a study which has as subject the promotion of Brazilian's tourism abroad through the dissemination of the typical country's cuisine. Its goal is to study the gastronomy as a cultural attraction in the subsystem of the market and as a promotional tool in terms of international marketing of EMBRATUR, in order to evaluate the promotional marketing strategies aimed to attract international tourism, defined in the "Project Moviment of Valorization of Brazilian Gastronomy Abroad", especially durring the event "Stars of Gastronomy", held in Santiago, Chile. The study consists of an evaluation of the actions in the promotional marketing plan of this event, Verifying if the desired return intended on the basic design and how to measure its results was satisfactory. The results show that the event was very important and that, in fact, it contributed to the spread of Brazilian tourism, despite some inconsistencies and lack of accurate tools to measure the result to be achieved.
\end{abstract}

Keywords: tourism, culture, gastronomy, marketing, promotion, captation. 


\section{LISTA DE ILUSTRAÇÕES}

Figura 1- Sistema de Turismo (SISTUR) - modelo referencial....................................... 25

Figura 2- Estrutura Organizacional da EMBRATUR ................................................... 43

Figura 3- Organograma do Plano Aquarela .................................................................... 44

Figura 4- Marca Brasil ............................................................................................ 46

Figura 5- Países Prioritários para promoção do Brasil - Chile $3^{\circ}$ país/altíssima Prioridade 


\section{LISTA DE QUADROS}

Quadro 1:composição de um ambiente de marketing - Ambiente

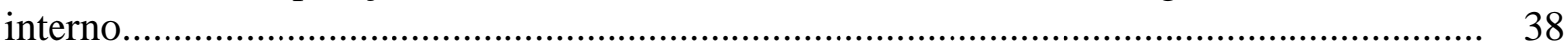

Quadro 2:composição de um ambiente de marketing - Ambiente

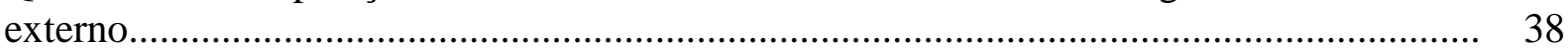

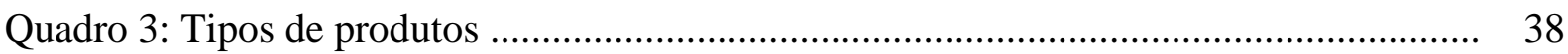

Quadro 4: Pontos fortes e Pontos fracos do evento ........................................................ 60

Quadro 5: Cronograma de execução (meta, etapa ou fase) .............................................. 61 


\section{LISTA DE GRÁFICOS}

Gráfico 01: Resultado da enquête realizada pela Folha On-line sobre: "Qual a primeira coisa que você [leitor] procura informações antes de fazer uma

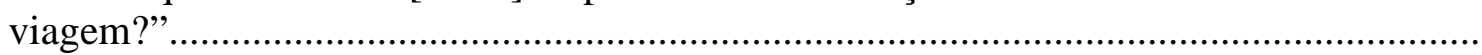




\section{SUMÁRIO}

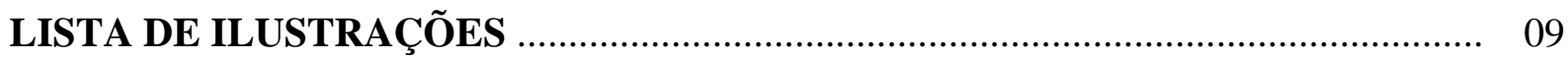

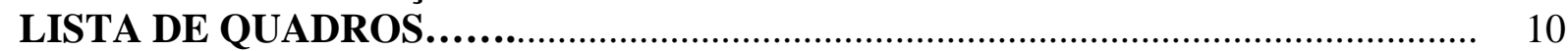

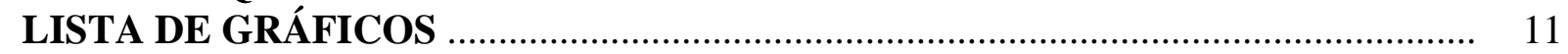

1-INTRODUÇÃ O

2-METODOLOGIA.

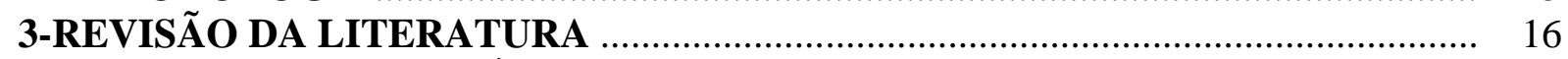

3.1 - DA ALIMENTAÇÃO À GASTRONOMIA …………...................................... 16

3.2-TURISMO:ASPECTOS CONCEITUAL …………………………………........ 21

3.2.1 - O crescimento do turismo ……................................................................. 23

3.2.2 - O modelo referencial "SISTEMA TURÍSTICO - SISTUR" '............................... 24

3.2.3 - O Conjunto das Ações Operacionais ...………………………………………... 26

1.3 - MARKETING ………………………………………………………... 34

1.3.1 - Orientação para marketing ……………………….................................. 35

4-AS PARCERIAS DO "PROJETO MOVIMENTO DE VALORIZAÇÃO DA GASTRONOMIA BRASILEIRA NO EXTERIOR" PARA PROMOÇÃO DO TURISMO BRASILEIRO NO EXTERIOR .

2.1 - INSTITUTO BRASILEIRO DE TURISMO - EMBRATUR ……………………..... 43

2.2 - O PLANO AQUARELA ............................................................................ 44

2.3 - PROJETO MOVIMENTO DE VALORIZAÇÃO DA GASTRONOMIA BRASILEIRA NO EXTERIOR ………………………....................................... 48

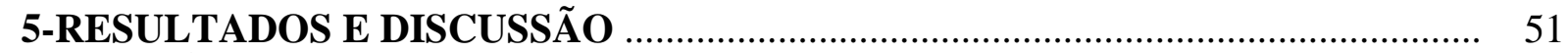

3.1 - ANÁLISE AMBIENTAL DO EVENTO ……………......................................... 51

3.2 - CRITÉRIOS DEFINIDOS NOS OBJETIVOS DO PROJETO ................................. 51

3.3 - ESTRATÉGIAS DE MARKETING UTILIZADAS PARA ATINGIR OS

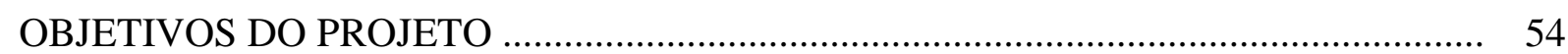

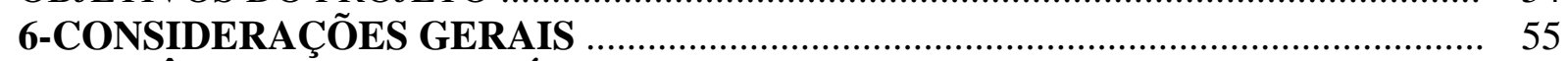

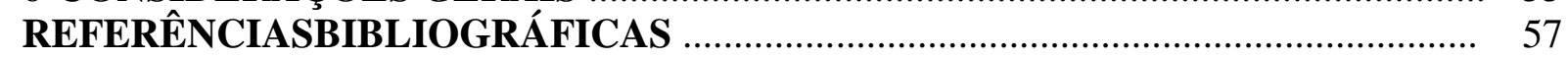

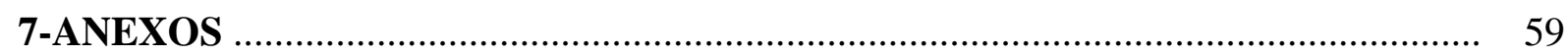




\section{INTRODUÇÃO}

A partir da criação do Ministério do Turismo, percebeu-se a evolução da atuação do Governo Federal em relação à necessidade de definir uma política pública para o turismo em resposta a um ambiente político favorável, cujos valores e ideologias de compartilhamento de distribuição do poder propiciaram a implantação de estruturas institucionais compatíveis e de processos integrados de tomada de decisão.

O turismo assume lugar entre os fatores de desenvolvimento social e econômico e deve, obrigatoriamente, figurar no universo das escolhas administrativas e legislativas como uma das alternativas preferenciais para o alcance do desenvolvimento social e econômico. A potencialidade econômica deve ser propulsora do desenvolvimento social sob os esforços da União, dos Estados, do Distrito Federal (DF) e Municípios e dirigirem-se à concretização de resultados econômicos e sociais (art. 1, inciso I e II, da Constituição Federal, doravante CF).

O rápido crescimento e desenvolvimento do turismo no Brasil reclamaram respostas específicas do setor público aos impactos do turismo exercidos em determinados destinos. O planejamento significa prever e regular a mudança em um sistema e promover um crescimento ordenado a fim de aumentar os benefícios sociais, econômicos e ambientais do processo de desenvolvimento. O planejamento deve ser estratégico e integrador, pois no processo de planejamento podem-se evitar impactos negativos. Para tanto, todos os participantes e atores direta ou indiretamente interessados no objetivo do plano a ser elaborado devem estar envolvidos.

De maneira geral e de acordo com as recomendações da Organização Mundial do Turismo - OMT (1998), os impactos positivos e negativos advindos da atividade turística devem ser monitorados, e pertencem a três categorias distintas: impactos ambientais; impactos socioculturais; impactos econômicos.

Um dos meios de desenvolver de forma mais sustentável o turismo é a incorporação de princípios de desenvolvimento sustentável aos planejamentos e às operações.

Para tanto é essencial entender que o turismo implica numa interação entre viajantes e comunidades receptoras e demanda uma ampla variedade de serviços, instalações e tecnologias que geram oportunidades e desafios para os núcleos receptores e destinos turísticos. 
A perspectiva de ser a gastronomia um importante fator de estímulo ao turismo, por se constatar que as pessoas, quando viajam, querem um lugar bom para se alimentar, recompor as energias, incitou uma reflexão sobre o uso da gastronomia como ferramenta de comunicação e de promoção da atividade turística.

A gastronomia é relevante para o turismo; e, a partir da interpretação do Decreto $\mathrm{n}^{\mathrm{o}} 3.551$ (agosto de 2000), foi instituído oficialmente como parcela do patrimônio imaterial, tornando-se de importância singular, peculiar e única, uma vez que se constitui num dos muitos atrativos culturais e concorre para a composição da imagem das regiões em seu complexo universo local e global. A alimentação pode refletir a história, o clima, a vegetação e o cultivo como elementos de memória de um povo.

Para tal, é necessário tomar os instrumentos da gestão pública federal para atividade turística como objeto de estudo quanto à aplicabilidade e distribuição frente aos impactos resultantes dos processos de consumo de bens, serviços e paisagens.

Nesse sentido, o presente estudo tem como base a formulação de uma proposta para a gastronomia como atrativo cultural no subsistema turístico, como mercado e ferramenta promocional no Plano de Marketing Internacional da EMBRATUR (Instituto Brasileiro de Turismo).

O presente trabalho é um estudo sobre a análise estratégica, tática e operacional do evento realizado em Santiago no Chile, em dezembro de 2008 por tratar-se de uma parte da série de ações integrantes do "Projeto Movimento de Valorização da Gastronomia Brasileira no Exterior".

Tem como objetivo geral examinar a proposta de divulgar a gastronomia como atrativo cultural no subsistema turístico do mercado, e discutir se a ferramenta promocional no plano de marketing internacional da EMBRATUR atingiu as metas previstas quanto a captação de turistas internacionais por meio da promoção da gastronomia brasileira. Especificamente, pretende:

- avaliar as ações previstas no plano de marketing promocional do evento "Estrelas da Gastronomia" do Chile;

- identificar as ameaças e as oportunidades do ambiente externo;

- identificar os pontos fracos e os pontos fortes internos da organização do evento "Estrelas da Gastronomia"; 
- avaliar o retorno pretendido no projeto básico e como foi definida a forma de mensuração da satisfação dos objetivos estabelecidos.

O trabalho será desenvolvido de acordo com a seguinte estrutura: metodologia, revisão da literatura, análise da situação, resultados e considerações finais. 


\section{METODOLOGIA}

A presente pesquisa é um estudo de caso. A amostra foi o "Projeto Movimento de Valorização da Gastronomia Brasileira no Exterior" e a participação e validação dos serviços ofertados no evento "Estrelas da Gastronomia". Esse evento foi realizado em $\underline{\text { Santiago do Chile, no período de } 01 \text { a } 07 \text { de dezembro de } 2008 \text { e se destinava a um }}$ público de aproximadamente 60 pessoas. O período escolhido se deve ao fato de ter sido pactuado no objeto do convênio.. Destinava-se a atender a um público formador de opinião como: operadores, jornalistas, empresários do local e agentes de viagens .

\subsection{Instrumento e coleta de dados}

Para analisar esse evento, não foi desenvolvido nenhum instrumento específico pelo órgão responsável. As observações foram feitas a partir de análises presenciais realizadas pelo representante da EMBRATUR.

Os dados foram coletados no período de 01 de novembro a 01 de dezembro de 2008, por meio de visita técnica ao evento "Estrelas da Gastronomia", parte do "Projeto Movimento de Valorização da Gastronomia Brasileira no Exterior", bem como, na Embratur, do Plano Aquarela e nos restaurantes brasileiros em Santiago, participantes do festival.

\subsection{Evento}

No período de 01 a 07 de dezembro, a Semana da Gastronomia Brasileira, parte do "Projeto Movimento de Valorização da Gastronomia Brasileira no Exterior", apresentou, nos melhores restaurantes brasileiros, da capital chilena, as maravilhas da culinária brasileira.

Habitantes e visitantes da cidade de Santiago tiveram a oportunidade de apreciar a riqueza e a diversidade da cozinha brasileira, com a participação de seis dos principais restaurantes da nossa culinária lá estabelecidos.

Entre as ações previstas estava a realização de um minifestival em que cada restaurante escolheu um prato do seu cardápio para ser destaque do evento. Os clientes que passaram por esses restaurantes, além de degustarem o "prato do festival", foram informados sobre os encantos culturais, naturais e turísticos do Brasil. 


\section{REVISÃO DA LITERATURA}

Há mais de dois mil anos o Senhor DEUS fez do solo brotar toda sorte de árvores agradáveis à vista e boas para alimento. (GÊNESIS 2:9)

\subsection{DA ALIMENTAÇÃO À GASTRONOMIA}

A alimentação cumpre uma função biológica, pois fornece ao corpo as substâncias indispensáveis para sua subsistência. Os alimentos permitem incorporar elementos que proporcionam ao organismo os nutrientes essenciais para sua existência, razão pela qual se faz necessária uma seleção de acordo as atividades que o homem realiza. Ela é um processo consciente e voluntário que se ajusta a diferentes normas segundo cada cultura. Por seu intermédio, o ser humano é socializado desde o seu nascimento. Desse modo, o conceito de alimentação implica tanto os processos nutritivos e a regulagem e o controle dietético, como o marco cultural e social em que se localizam esses comportamentos e normas alimentares. (SCHLUTER, 2003, p. 13)

A alimentação não é apenas um instrumento que permite saciar a fome; é um meio de se transmitir um significado simbólico em uma determinada sociedade. Apesar de partirem de elementos similares, distintas culturas preparam sua alimentação de diversas formas. Essa variedade na preparação dos pratos está condicionada pelos valores culturais e códigos sociais em que as pessoas se desenvolvem. (SCHLUTER, 2003, p. 16)

Comida se distingue de alimento. Ambas as noções são socialmente construídas e devem ser percebidas em seu contexto. Ainda que sejam próximas, não se confundem. Basta lembrar que quando vamos a certo tipo de restaurante, desejamos comer "comida italiana", "comida balinesa" etc. e não "alimento italiano" ou "alimento balinês". De acordo com Damatta (2001), essa distinção entre comida e alimento é, acima de tudo, uma diferenciação qualitativa, pois a comida traz em si a noção cultural, ela é uma das partes da cultura do país. A comida, além de conter o aspecto de sua origem, contém, também, a forma típica de fazer. Ela não só define o que é comido, mas também aquele que a ingere. No caso do Brasil, Damatta (2001) ressalta que até o fato de a comida típica do país ser o "feijão com arroz" é prova contundente do costume brasileiro de "miscigenar".

Além disso, a categoria alimento se refere a um "vir a ser", a algo que poderá potencialmente ser consumido. Para que o alimento se torne comida ele deve, via de 
regra, sofrer um processo de transformação qualitativa, realizando a passagem do plano da natureza para o da cultura pela via da culinária.

Porém, nem todo alimento se transforma em comida. Existem aqueles que são exclusivos para uso animal. Cascudo (2001) salienta que existem também os alimentos proibidos, como aqueles que fazem parte das abominações. De acordo com o autor, vários exemplos são arrolados no livro bíblico Levítico, capítulo 8. Há, ainda, o muçum, no Rio Grande do Sul, que não é comido por ser um bicho esquisito: é do mar, mas não é peixe, parece cobra.

É sabido, ainda, que a satisfação das necessidades nutricionais é condição indispensável á sobrevivência dos seres humanos. Contudo, os significados da alimentação não podem ser apreendidos apenas a partir de indicadores nutricionais. De acordo com Fischler (1979, p.1) o homem é um onívoro que se alimenta de carne, de vegetais e de imaginário.

No que concerne à gastronomia, palavra proveniente do grego antigo $\gamma \alpha \sigma \tau \rho o v o \mu i ́ \alpha ; \gamma \alpha \sigma \tau \rho \varsigma^{1}$ ["estômago"] e vouía ["lei"/"conhecimento"]), é um ramo que abrange a culinária, as bebidas, os materiais usados na alimentação e, em geral, todos os aspectos culturais a ela associados. Seu estudo veio para preencher lacunas antes deficientes com relação ao entendimento sob os aspectos sociais, históricos, técnico, biológico, turístico entre outros.

Sob o aspecto do turismo, a gastronomia estimula as pessoas, pois quando viajam, querem um lugar bom para se alimentar, recarregar as energias. Também querem conhecer o povo, suas tradições e costumes, o que passa pela culinária típica local. Quando viajam, muitos regulam o seu tempo pelas refeições, assim como, nos aviões, espera-se ansiosamente por este momento. O segmento tem crescido muito nos últimos anos, empregando atualmente cerca de nove milhões de pessoas.

De acordo com Furtado (2004), as pessoas buscam novos conhecimentos, querem experimentar novos sabores, vivenciar outras culturas e a gastronomia pode ser o motivo principal, ou o inicial, para se conhecer determinado local. Por exemplo, ir a uma festa típica, em Blumenau - Santa Catarina, e experimentar comidas típicas. A festa e a localidade têm as suas atrações, mas a comida pode ser o diferencial para a escolha desse local. Isso também ocorre, por exemplo, no Chile, com suas vinícolas e seus pescados únicos; na França, com sua culinária requintada e tradicional; na Itália, com

\footnotetext{
${ }^{1}$ http://pt.wikipedia.org/wiki/Gastronomia
} 
suas diversas variações e, ainda, no exotismo da culinária oriental, como no Japão, China e Tailândia, entre outros. O que não falta são variações e novidades, e o turismo possibilita essas descobertas. Ambos possuem uma relação estreita: gastronomia e turismo.

A gastronomia é, dessa forma, considerada importante e relevante para o turismo, e possibilita inúmeras oportunidades para todos aqueles que souberem explorar direta ou indiretamente esse nicho de mercado. Os exemplos citados mostram que a gastronomia como produto turístico é um importante motivador e, mesmo quando não é o motivo e/ou elemento principal, ela sempre estará inserida no contexto e terá o seu papel de destaque num evento turístico, como numa viagem, passeio, feira, ou reuniões.

A gastronomia é um componente importante da oferta de um destino turístico, pois todos os turistas necessitam se alimentar. Tratando-se da principal motivação ou de uma simples necessidade, pode ter um elevado peso no consumo efetuado pelos turistas. A gastronomia típica é uma ferramenta pela qual um país, uma região ou uma localidade pode manifestar o modo de ser e de fazer de um povo.

Em 04 de agosto de 2000, O Decreto $\mathrm{n}^{\mathrm{o}} 3.551$ instituiu o Registro de Bens Culturais de Natureza Imaterial que constituem patrimônio cultural brasileiro, criando o Programa Nacional do Patrimônio Imaterial e dando outras providências. (IPHAN Instituto do Patrimônio Histórico e Artístico Nacional, 2000. p. 25)

Esse Decreto veio para instituir o apontamento dos bens imateriais que constituem o registro em livros referentes às técnicas, à elaboração, à construção dos processos, às práticas, aos rituais e a tudo o que se relaciona ao saber de um povo e não apenas à elaboração de uma receita.

Acrescente-se a isso que o patrimônio imaterial é um segmento muito importante no turismo, pois, além de oferecer oportunidades de degustação de pratos e de bebidas, atrativos importantes, produz renda à população nos mais distintos recantos.

A gastronomia consegue, assim, importância no turismo seguindo a busca pelo singular, peculiar e único encontrado em cada região, com sabores da terra, sabores únicos. A alimentação pode refletir a história, o clima, a vegetação, o cultivo como elementos de memória de um povo.

Para que se esclareça a relação entre culinária e patrimônio imaterial, precisa-se primeiramente, realizar uma discussão acerca do patrimônio em si. O conceito de patrimônio originalmente esteve ligado à questão de pertença de bens, principalmente os materiais, como nos mostra Barreto (2003) em sua definição deste: "conjunto de 
bens que uma pessoa ou uma entidade possuem (...)" De acordo com o autor, "Transportado a um determinado território, o patrimônio passa a ser o conjunto de bens que estão dentro de seus limites de competência administrativa" (BARRETO, 2003) Todavia, a idéia de patrimônio foi requalificada por diversos adjetivos, tais como natural, histórico e cultural.

Patrimônio cultural pode ser classificado como conjunto de bens materiais (tangíveis) e imateriais (intangíveis), não só as edificações e monumentos históricos ou as manifestações artísticas, mas todo o fazer humano, tudo o que o ser humano produz, de todas as classes sociais, tanto as mais quanto as menos favorecidas. (BARRETO, 2003, p. 11). Ou seja, patrimônio cultural é tudo aquilo que constitui um bem apropriado pelo homem - o que ele faz - com suas características únicas particulares o que é importante. Londres (2004), citando o anteprojeto da UNESCO aprovado na $32^{\mathrm{a}}$ Conferência Geral, realizada em outubro de 2003, nos mostra a seguinte definição de patrimônio imaterial:

\begin{abstract}
Segundo Londres (2004, p 22) "o patrimônio cultural intangível é constituído por práticas, representações, expressões, saberes e fazeres - assim como instrumentos, objetos, artefatos, e espaços culturais que lhe são associados - que comunidades, grupos e, quando for o caso, indivíduos reconhecem como parte de sua herança cultural. Esse patrimônio cultural imaterial, transmitido de geração em geração, é constantemente recriado por comunidades e grupos em resposta ao seu meio ambiente, sua interação com a natureza e suas condições históricas de existência, e lhes proporciona um sentido de identidade e continuidade, promovendo assim o respeito pela diversidade cultural e pela criatividade humana" (LONDRES, 2004, p. 22).
\end{abstract}

A manifestação cultural de um povo pode se traduzir por diversas formas pelos principais atrativos, como por meio de música, artesanato, festas, museus, obras de arte, sítios históricos, trabalhos manuais, gastronomia entre muitos outros. (Orientações Básicas - Turismo Cultural - Brasil - 2006 - Ministério do Turismo), e seus diversos desdobramentos constituem insumos básicos para o desenvolvimento do Turismo Cultural.

A cozinha de um povo constitui traço marcante de sua cultura, pois resulta nas características geográficas do local onde esse povo vive, sua formação étnica e suas crenças religiosas e políticas. No que diz respeito à culinária brasileira, ela tem uma singularidade, um valor intrínseco e um caráter brasileiro que representam a identidade nacional. 
É válido ressaltar, também, que quando um turista vai em busca de viajar, seja devido ao lazer ou por outros impulsos, ele é motivado por diversos fatores para escolher esse ou aquele lugar.

O Guia Quatro Rodas ${ }^{2}$ - Brasil 2006, p.108), no capítulo intitulado Turismo do Sabor, declara que: "Alguns pratos destacam-se no cardápio como verdadeiras atrações. Seja pela qualidade e combinação de ingredientes, criatividade ou preparo esmerado. Isso chama a atenção sobre a importância da gastronomia como atrativo para o Turismo. Terá ela poder de atrair o turista no momento de definição do seu roteiro de viagem ou de seu local de hospedagem?

Outro dado que leva ao questionamento sobre a real influência da gastronomia na escolha de destinações e locais de hospedagem referem-se aos resultados da enquete realizada em 2003 publicados no site Folha On-line ${ }^{3}$ (2004), do jornal Folha de São Paulo, sobre a importância dos fatores de influência na escolha de uma destinação turística (Quadro 1).

\section{Quadro 1: Resultado da enquete realizada pela Folha On-line sobre: "Qual a primeira coisa que você [leitor] procura informações antes de fazer uma viagem?"}

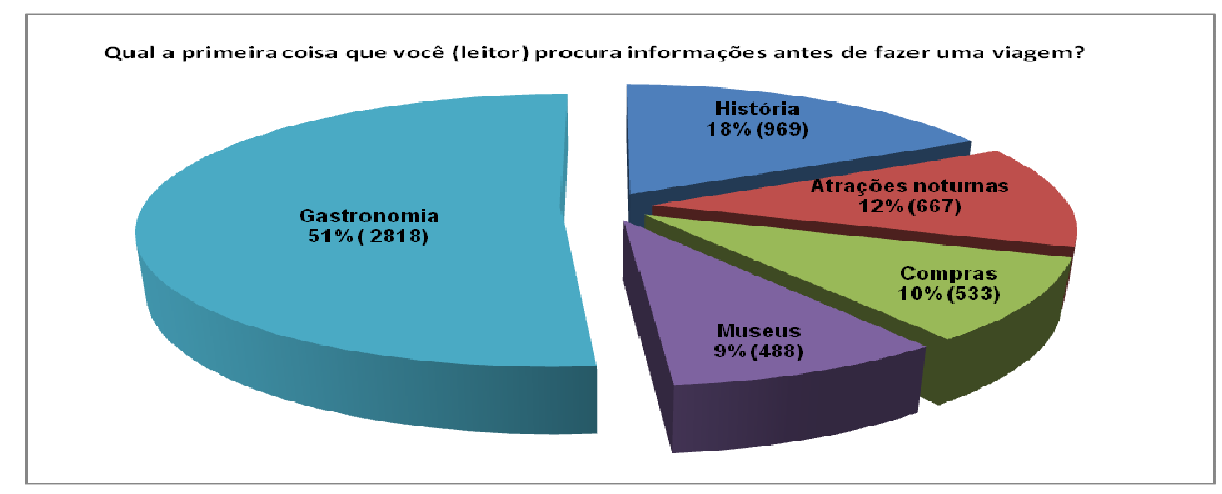

$<$ http://www.folha.com.br/>

Fonte:

Essa enquete teve a participação de 5.475 respondentes e revelou que, na concepção de $51 \%$ deles, a gastronomia é o principal quesito a ser considerado na busca de informações sobre uma viagem. Os demais itens foram: história (969 votos-18\%); atrações noturnas (667 votos - 12\%), compras (533 votos - 10\%) e museus (488 votos $9 \%)$.

2 Guia Quatro Rodas - Brasil 2006 foi lançado em outubro de 2005.

3 http://www.folha.uol.com.br/ 


\subsection{TURISMO: ASPECTOS CONCEITUAIS}

O turismo como fenômeno social complexo pode ter diferentes significados. Remete como objeto de estudo para um confronto com sua complexidade e abrangência. Complexo porque não existe uma definição de aceitação universal e abrangente devido à sua penetração em campos de várias ciências, tornando-se alvo de uma multiplicidade de abordagens.

$\mathrm{O}$ aspecto conceitual enfoca o turismo sob o ponto de vista dos diferentes conhecimentos, correntes de pensamento e do seu significado para a sociedade. sob o ângulo das diferentes áreas de conhecimento, constitui-se num vasto campo de estudo e, a discussão sistemática determinou a necessidade de sistematizar e definir o Turismo. Porém, essas definições são parciais, uma vez que se referem a aspectos muito específicos da atividade, e não a enfocam na sua magnitude. Por outro lado, o estudo do turismo a partir do seu significado para a sociedade buscou uma definição mais ampla, que abrangesse a atividade em um sentido geral, de caráter descritivo, procurando identificar características essenciais.

Segundo Luis Fernando Jimnénez (1982) propõe a seguinte definição:

Turismo, no sentido moderno da palavra, é um fenômeno dos tempos atuais, baseado na crescente necessidade de recuperação e mudança de ambiente, no conhecimento e na apreciação da beleza dos cenários, no gozo do contato com a natureza e é, em particular, produto da crescente fusão das nações e países da sociedade humana, como resultado do desenvolvimento do comércio, da indústria e dos mercados e do aperfeiçoamento dos meios de transporte. ${ }^{4}$

Apesar de essa definição apresentar uma idéia a respeito do fenômeno turístico, muitos especialistas, não satisfeitos, iniciaram o que hoje se conhece como o estudo científico de turismo - a Escola Berlinesa.

Nessa escola foi desenvolvida uma série de definições e conceitos de turismo, sendo que, em 1942, foi elaborada, pelos professores suíços Hunziker e Krapf, a seguinte definição:

\footnotetext{
4 JIMMÉNEZ G., Luis Fernando. Apuntes de la cátedra sobre teoría turística. Bogotá: Universidad del Externado de Colombia, 1982.
} 
Turismo é o conjunto das relações e fenômenos produzidos pelo deslocamento e permanência de pessoas fora de seu lugar de domicílio, desde que esses deslocamentos e permanências não estejam motivados por uma atividade lucrativa principal, permanente ou temporal. (JIMMÉNEZ, 2002)

Essa definição foi a mais aceita entre os experts e foi adotada pela Associação Internacional de Especialistas Científicos em Turismo - AIEST. Porém, essa acepção é extremamente técnica e deixa a desejar no que se refere ao significado do turismo para a sociedade.

Pode-se se dizer que ele está relacionado a atividades de recreação, lazer, descanso, desenvolvimento cultural e prazer. Dessa forma, é visto como o uso do tempo livre dedicado ao entretenimento, esporte, viagens, enfim, às atividades prazerosas.

$\mathrm{Na}$ abordagem turismo tempo livre e qualidade de vida, ele é visto como uma atividade essencial para o equilíbrio pessoal e para a saúde. Diante da sociedade moderna, o tempo livre assumiu uma dimensão muito ampla, se tornando, até mesmo, uma necessidade para uma boa qualidade de vida.

Nessa perspectiva, o turismo é concebido como uma atividade que tem lugar no tempo livre e contribui de maneira significativa para boas condições de saúde, física, educação, entre outras.

Do ponto de vista técnico, o turismo assume várias definições, caracterizado em relação aos propósitos de cada setor. As principais definições de caráter técnico surgiram da necessidade específica de alguma disciplina ou algum tipo de atividade. Difere-se do aspecto conceitual do turismo no fato de a atividade se relacionar com o uso do tempo livre e com a recreação.

Um método utilizado para entender o complexo sistema de turismo é a Teoria Geral dos Sistemas, que enfoca o estudo do turismo relacionado entre diversas disciplinas e suas inter-relações.

Embora não haja uma definição consensual para o Turismo, as recomendações da Organização Mundial de Turismo/Nações Unidas sobre Estatísticas de Turismo, o definem como "as atividades que as pessoas realizam durante suas viagens e permanência em lugares distintos dos que vivem, por um período de tempo inferior a um ano consecutivo, com fins de lazer, negócios e outros." 


\subsubsection{O crescimento do turismo}

O processo da globalização levou a uma ampliação sem precedentes no mercado. A demanda pelo turismo internacional se desenvolveu em um ritmo comparado ao da aviação civil, que também se beneficiou muito com a globalização, ou seja, teve um pouco acima da média do crescimento no mercado mundial e da economia mundial como um todo. Isso levou a uma proliferação de destinos. As ofertas de assentos na aviação civil e de vagas no setor de hospedagem, simultaneamente, cresceram a ponto de se tornarem uma sobre oferta, o que já está afetando os preços que os prestadores de serviços podem cobrar. Aproximadamente dois terços do turismo internacional se concentram nos países mais desenvolvidos da Organization for Economic Coorperation and Developmente - OECD. (EMBRATUR)

Esse mercado turístico se caracteriza por preferências similares de demanda e produtos e serviços comparáveis. Além disso, os países industrializados contam com fortes mercados domésticos e de países vizinhos, um fato que suavizou o impacto do processo de globalização. O turismo internacional também se desenvolveu, nos últimos anos, nesse grupo de países. Mas eles enfrentam uma pressão competitiva crescente vinda de novos destinos, que geralmente se beneficiam de vantagens em termos de custos e taxas cambiais.

No espaço de apenas três décadas, os países emergentes e em desenvolvimento buscaram ampliar, de maneira notável, sua fatia de mercado internacional. Entre eles, um pequeno grupo de grandes países, que absorveram 90\% do fluxo de capital privado, foram os mais bem-sucedidos. Esse grupo inclui países considerados "gigantes" como China, Índia e Brasil. Os países pobres em desenvolvimento estão menos representados no mercado mundial de turismo, com exceção de algumas pequenas ilhas.

A grande rede de contatos criada pela tecnologia da informação deu condições para o surgimento de uma cultura global de lazer. A posição do consumidor foi aperfeiçoada nesse mundo globalizado. O programa de viagem, por exemplo, permite que turistas em potencial analisem visualmente o destino turístico que pretendem visitar, antes de efetivamente realizarem a viagem. Os novos sistemas de distribuição estão melhorando a transparência nos negócios tanto em termos de serviços como de preços. Essas melhorias também significam que as pessoas, em todo o mundo, passaram a adotar padrões similares relativos à expectativa do conforto e o padrão de qualidade de hoje são verdadeiramente internacionais. 
Em um momento em que uma cultura praticamente idêntica de turismo está surgindo em todo o mundo, os viajantes buscam, cada vez mais, experiências que sejam ao mesmo tempo exclusivas e típicas. Esses atrativos exclusivos podem ser paisagens ou patrimônios históricos, ou produtos que lembrem pontos turísticos, como parques temáticos ou cruzeiros oceânicos. (KELLER, 2002).

\subsubsection{O modelo referencial "SISTEMA TURÍSTICO - SISTUR"}

Em primeiro lugar, para entender o sistema de turismo - SISTUR é interessante definir o que é um sistema. Segundo Bancal, ${ }^{5}$ existem três definições de sistema:

A definição etimológica - conjunto de elementos associados em uma organização coerente, com o objetivo de constituir um todo;

A definição descritiva - conjunto organizado e estruturado de elementos materiais ou imateriais que constituem um todo ordenado e orientado e

A definição pragmática - conjunto de práticas, de métodos e de instituições que compõem, ao mesmo tempo, uma construção teórica e um método prático.

Nesse sentido, pode-se entender que sistema é um conjunto de diversos fatores, que se inter-relacionam entre si. Todos provocam, de alguma forma, algum efeito no outro.

Churchman $^{6}$ estabelece como primordial para o entendimento de sistema cinco considerações básicas:

1. Os objetivos totais do sistema e, mais especificamente, as medidas de rendimento do sistema inteiro;

2. O ambiente do sistema;

3. Os recursos do sistema;

4. Os componentes do sistema, suas atividades, finalidade e medidas de rendimento;

5. A administração do sistema.

Na perspectiva de Mário Beni ${ }^{7}$, podem-se citar como objetivos do SISTUR: estudar a atividade do turismo, fundamentar as hipóteses de trabalhos, justificarem posturas e princípios científicos, aperfeiçoar e padronizar conceitos e definiçõoes e consolidar condutas de investigação para instrumentar análises e ampliar a pesquisa.

Os recursos podem ser caracterizados como uma espécie de estoque de ações específicas do SISTUR. São os pontos de partida para a realização das tarefas.

\footnotetext{
5 BANCAL, J., L'économie des sociologues. Paris, PUF, 1974.

6 CHURCMAN, C. West The systems approach. Nova York: Dell Publishing, 1968.

7 BENI, Mário Carlos. Análise Estrutural do Turismo. São Paulo: SENAC, 2002.
} 
Os componentes configuram-se como os subsistemas que o sistema possui, que são: Conjunto das Relações Ambientais, da Organização Estrutural e das Ações Operacionais.

Em relação à administração do SISTUR, pode-se dizer que esta é a criação de planos para o sistema. É a administração que determina as finalidades dos componentes, procede à alocação de recursos e controla o rendimento do sistema. Outro importante papel da administração é assegurar que os planos sejam executados de acordo com suas idéias originais. Porém, caso haja alguma reavaliação do processo de retroalimentação de intervenção, em qualquer parte do sistema, cabe à administração efetuar os ajustes ou mudanças necessárias.

Figura 1 - Sistema de Turismo (SISTUR) - modelo referencial

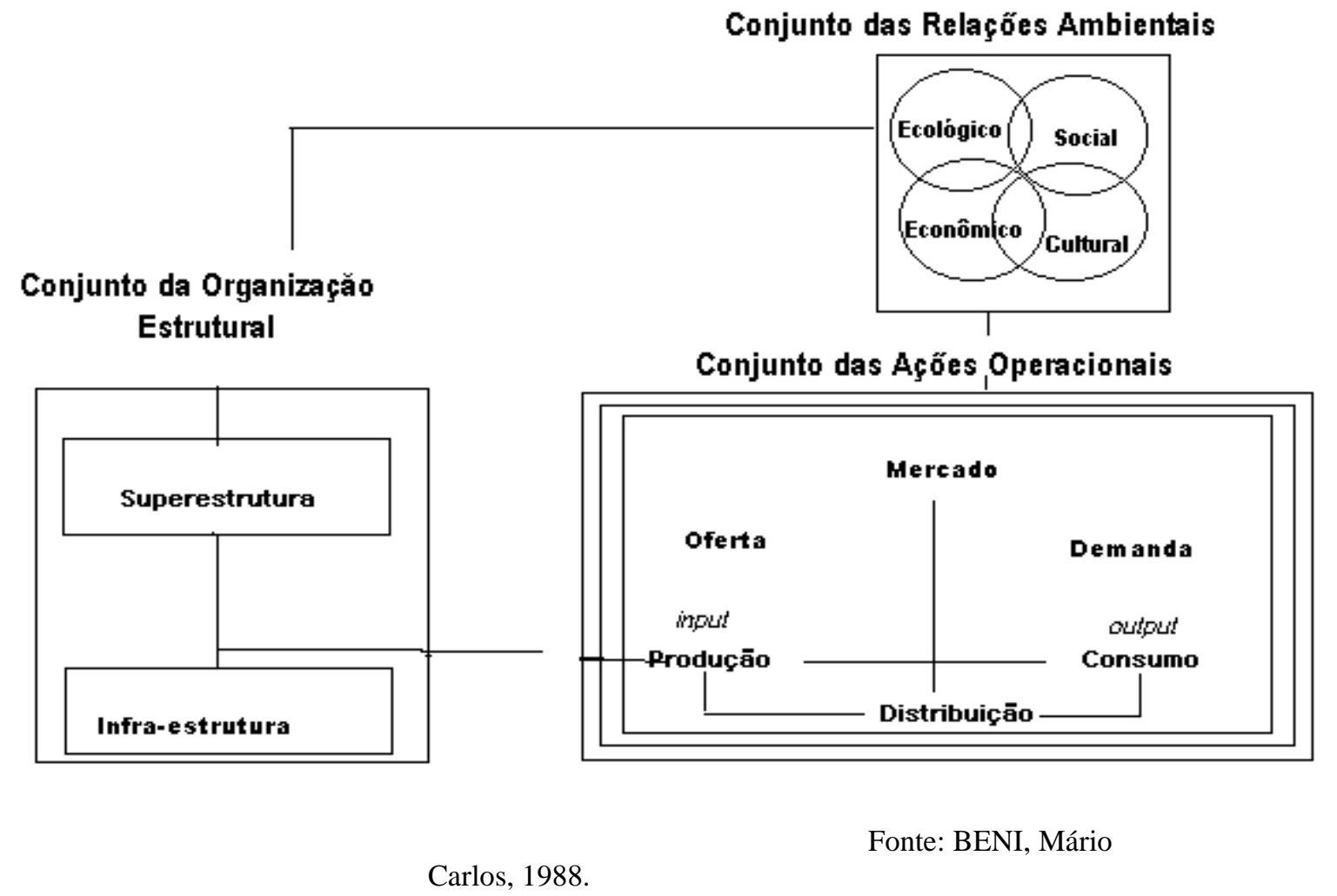

\subsubsection{O Conjunto das Ações Operacionais}

\section{O Subsistema do Mercado}

Entende-se por mercado todos os consumidores potenciais que compartilham de uma necessidade ou desejo específico e estão dispostos e habilitados a fazer trocas para realizar essas necessidades e/ou desejos (KOTLER, 1998). 
O mercado é nada mais do que a relação entre oferta e demanda de bens, serviços e capitais. No entanto, para estudá-lo, é interessante enfocar três questões: o que produzir, como produzir e para quem produzir:

O que produzir - Eficiência Atributiva: satisfazer as necessidades ilimitadas. Determina o que produzir, quantidade e qualidade de bens/serviços.

Como produzir - Eficiência Produtiva: visa produção ao menor custo, empregando a menor quantidade possível de recursos.

Para quem produzir - Eficiência Distributiva: resolve quem irá consumir os bens/serviços produzidos, com a condição de que cada consumidor tenha uma satisfação proporcional ao custo.

Essas são as funções básicas que cumprem os mercados e devem ser resolvidas simultaneamente. Segundo Martini ${ }^{8}$, a classificação do mercado se categoriza sob três pontos de vista ou perspectivas:

Geográfica: maior ou menor se forem numerosas ou escassas as pessoas que demandam os bens envolvidos no processo de comercialização.

Temporal: distinguidos quanto ao período durante o qual se efetua o ajuste entre a oferta e a procura, ou seja, a formação do preço.

Concorrência: que se divide em:

- Concorrência perfeita: há muitos produtores, nenhum influencia no preço, competidores novos têm liberdade de produzir nas mesmas condições dos produtores existentes.

- Concorrência imperfeita: capacidade de influenciar na demanda, usando práticas como diferenciação do produto, marcas e propagandas; existem restrições ao ingresso de novos competidores; incerteza e desconhecimento imperfeito sobre preços e lucros e ausência de competição de preços, em que há possibilidade de produtos substitutos.

- Monopsônio: existe apenas um único comprador.

- Monopólio: existe apenas um único vendedor.

- Oligopólio: o produto é oferecido por um pequeno número de empresas, com atividades e políticas de produção determinadas pelas reações esperadas de uma outra.

\footnotetext{
8 MARTINI, Xavier J. Elementos de análisis econômico del turismo. Buenos Aires: Turística S.R.L.,
} 1983. 
- Duopólio: há somente dois vendedores, e a influência de um deles sobre o preço é bastante considerável.

Em relação ao Mercado de Turismo, pode-se dizer que existe para cada produto turístico um tipo de mercado: um real e um potencial. O Mercado de Turismo se caracteriza por ser de concorrência imperfeita, os produtos são diferenciados, porém, não são homogêneos nem intercambiáveis.

Distingue-se o Mercado de Turismo em dois mercados: o do produto turístico (quando o consumidor compra. Exemplo: pacote turístico) e o do insumo (são os fornecedores. Esse mercado depende do que acontece no outro: caso dos pernoites hoteleiros).

A melhor forma de estudar o Mercado do Turismo é por meio da segmentação. Um dos pontos críticos no planejamento de marketing são a identificação e conhecimento dos mercados-alvos, ou seja, os consumidores. A segmentação consiste em decompor a população em grupos homogêneos, sendo o motivo da viagem o principal meio para segmentar o mercado.

O objetivo básico da segmentação é concentrar esforços de marketing em determinados alvos que a empresa entende como favoráveis para serem explorados comercialmente, em decorrência de sua capacidade de satisfazer à demanda desses públicos de maneira mais adequada.

As principais variáveis utilizadas como base para a segmentação dos mercados são:

Variáveis Geográficas (país, estado, regiões, municípios ou bairros);

Variáveis Demográficas (tamanho da família, ocupação, educação, religião, raça, nacionalidade, idade, sexo e renda);

Variáveis Psicográficas (classe social, estilo de vida e personalidade) e;

Variáveis Comportamentais (ocasiões, benefícios procurados, condição do usuário e taxa de uso, grau de lealdade).

No que se refere à competitividade do mercado, primeiramente é válido ressaltar que não há países turísticos (são as regiões que formam esse território turístico) competitivos, e sim produtos turísticos competitivos. A competitividade é determinada pelo baixo custo de mão-de-obra, juros baixos e taxas de câmbio favoráveis, além de depender da capacidade do setor em inovar e melhorar permanentemente a qualidade de sua oferta. 
Para que um mercado mantenha-se competitivo é preciso que haja concorrentes, produtos substitutos, poder para comercializar a demanda, poder de negociar a oferta e produtividade da empresa.

Nesse sentido, o Mercado de Turismo precisa manter a qualidade dos produtos e serviços, sendo esse o principal critério para êxito ou fracasso dos produtos e serviços. Essa deve ser a estratégia usada e aplicada para garantir a permanência competitiva no mercado.

\section{Os Subsistemas da oferta, produto, distribuição e demanda}

A oferta turística se caracteriza como o conjunto de recursos culturais e naturais, agregados aos serviços oferecidos - alimentação, hospedagem, recreação etc. Na realidade, a oferta só existe a partir do momento que surge o consumidor que deve conhecer o produto turístico oferecido, do contrário este produto não está sendo ofertado. .Para uma análise da oferta é interessante estudar seus enfoques, que se dividem em:

Oferta original - são os serviços gratuitos e imateriais (praias, sol, cultura, mar, etc.), constituem a matéria-prima da oferta. Contudo são elementos únicos, não podem ser substituídos, cabendo à sociedade e ao governo preservá-los;

Oferta agregada - são os serviços que complementam a matéria-prima (transporte, alimentação, hospedagem, recreação, agências de viagens e organizadores de viagens).

Quando se estuda oferta, geralmente, analisam-se as preferências e as motivações dos consumidores, para de fato, poder adequá-las aos desejos e necessidades destes. Porém, a oferta turística só poderá ser alterada em longo prazo e após conhecer profundamente a demanda, uma vez que os equipamentos turísticos não podem modificar-se com rapidez, afinal foram projetados para durarem.

Nesse sentido, é preciso conhecer com fidelidade a demanda e elaborar o plano de conversão do equipamento, para partir para investimentos com propaganda e publicidade, atraindo uma demanda que, de outra forma, se veria diminuída e alcançando o objetivo esperado, que seja intensificar a necessidade de maior capacidade receptora, aproximando a oferta da demanda.

O produto turístico se configura como o resultado de combinações de vários fatores de produção. Pode-se considerar como fatores primordiais para o 
desenvolvimento do processo de turismo: o patrimônio turístico nacional; a empresa de turismo; a infra-estrutura de apoio; o transporte; a comunicação; o saneamento básico e ambiental e os serviços públicos.

Como nos outros setores da economia, a produção de bens e serviços turísticos é analisada a partir do Processo Produtivo; do Processo Distributivo e do Processo de Intercâmbio (consumo).

Para entender o que seria a produção do produto turístico é necessário ter a visão de que são diversos os fatores que se combinam aos recursos turísticos, como, por exemplo, tecnologia, trabalho e capital para, então, resultar no produto final turístico.

Para analisar quais os preços dos fatores de produção, a maneira de determinação de salários, rendas, lucros, benefícios etc., utiliza-se do Processo Distributivo. Esses valores são verificados tendo como base a oferta e a demanda.

O Processo de Intercâmbio, ou seja, o do consumo, uma vez que a produção e o consumo do produto turístico acontecem no mesmo lugar. É necessário o deslocamento do turista para o local onde são produzidos os bens e serviços. Outros fatos a serem considerados é que o produto turístico é intangível, não poder ser estocado, nem transportado ou transferido, sua matéria-prima não se agrupa, está baseado no fator tempo, é extremamente dinâmico e instável, pelos gostos, preferências, modas e é opcional na escala de necessidade do consumidor.

Além dos fatos de sua qualidade ser experimentada, seus atributos só podem ser percebidos ou constatados na hora em que estão sendo consumidos, e no processo de "venda" haver um grande envolvimento de várias empresas, sua qualidade pode ser comprometida pela multiplicidade de contados diretos entre a empresa e o cliente.

Distribuição pode ser caracterizada simplesmente como o processo de levar o produto ou serviço ao consumidor final. Porém, para tanto é necessário utilizar uma estratégia de marketing para disponibilizar esses produtos ou serviços aos consumidores da melhor forma possível.

É também de vital importância saber distribuir os produtos ou serviços certos, aos consumidores certos. É imprescindível que a empresa encarregada da distribuição conheça seus consumidores e tenha a consciência do poder que têm em relação à decisão final do consumidor. 
Segundo Schomll ${ }^{9}$, o processo de distribuição está relacionado com três decisões básicas:

1. Escolha de métodos e canais de distribuição - apresenta três opções de ser realizada: a empresa efetua a distribuição e a venda diretamente aos consumidores; a empresa pode optar por intermediários, como as operadoras turísticas e agências de viagens; a empresa pode optar também pela venda direta e por meio de intermediários simultaneamente;

2. Organização da distribuição e das atividades de vendas - esta opção irá depender do método de distribuição escolhido. Se for pelo método de distribuição e venda direta, a empresa será responsável com todas as despesas relativas às viagens, treinamento, pessoal, entre outras. Caso a opção for pelo método de distribuição indireta (por meio de intermediários, utilizando operadoras turísticas e agentes de viagens), a empresa disporá de uma organização de venda de menor porte.

3. Atividades de apoio à distribuição e às vendas - se refere ao material promocional e de divulgação que é enviado aos intermediários e transmitido aos consumidores, com o intuito de os produtos turísticos tornarem conhecidos do público.

Para se comentar sobre a estrutura da distribuição turística é necessário lembrar, fato já comentado no Subsistema de Produção, que o produto turístico resulta no trabalho de diversas empresas, sendo que o produto turístico final é impossível de ser produzido por uma única empresa. Nesse sentido, cada empresa é responsável pelo desenvolvimento do Marketing de Turismo.

De acordo com Krippendorf, ${ }^{10}$ para identificar quais empresas podem ser enquadradas na denominação empresas de turismo, basta selecionar aquelas que fornecem, não importa de que forma, prestações materiais ou serviços turísticos, aquelas importantes para os turistas e que desempenham papel significativo no conjunto de Marketing Turístico.

Outro fator de notável relevância para a demanda turística é o marketing. As estratégias de marketing podem ser utilizadas para fazer com que os turistas tenham conhecimento de um local e desejem visitá-lo e para motivar os consumidores a adquirirem os produtos e/ou serviços turísticos.

As estratégias de marketing sempre direcionam seu principal foco nos consumidores, utilizando estes como ponto de partida para as estratégias de motivações desenvolvidas para uma destinação.

\footnotetext{
9 SCHOMOLL, A. C. Tourisme et marketing. Madri: OMT, 1974.

${ }^{10}$ KRIPPENDORF, J. Marketing et tourisme. Études Bernoises de tourisme.Berna: Hubert Lang et Cie. 1971.
} 
Para um melhor entendimento do Marketing Turístico é válido ressaltar, de acordo Middleton, que "o Marketing de Turismo é de vital importância, pois representa a principal influência do gerenciamento que pode ser aplicada ao tamanho e comportamento deste importante mercado global" ${ }^{11}$.

O marketing de Turismo é baseado no estudo de bens intangíveis, e na perspectiva de Krippendorf (1971):

é a adaptação sistemática e coordenada da política das empresas de turismo, tanto privada como do Estado, no plano local, regional, nacional e internacional, visando à satisfação das necessidades de determinados grupos de consumidores, obtendo, com isso, um lucro apropriado.

As motivações referentes a uma viagem constituem o fator principal de uma segmentação do mercado turístico, pois se não existissem dados indicadores da demanda turística, seria impossível determinar uma política voltada para cada destinação.

A demanda turística é devida ao movimento da viagem, ou seja, o movimento entre dois pontos - o emissor e o receptor. São indispensáveis para a formação da demanda: tempo livre, renda disponível e motivação para viajar, uma vez que é impossível realizar o movimento da viagem sem esses fatores.

Para ter um controle da demanda turística pode-se medi-la levando em consideração o total de turistas que entram em um destino turístico. Caso se deseje um estudo mais profundo desse controle, devem ser analisados os gastos e os tipos de serviços utilizados nos destinos turísticos.

Mas, para que estudar a demanda turística? Estudos respondem justificando o fato de que para se obter um turismo que ocorra em um maior desenvolvimento e sustentabilidade dentro das localidades receptoras é necessário ter um controle sobre o fluxo de turistas. Outro fato importante é que esses estudos possibilitam fazer um prognóstico sobre o desenvolvimento futuro, ou seja, saber como estará a localidade após alguns anos.

O estudo da demanda pode ser entendido como o conhecimento do consumidor do produto turístico, uma vez que para escudá-la são levadas em consideração as motivações, atitudes e características dos indivíduos que fazem turismo.

\footnotetext{
11 MIDDLETON, Victor T. C. Marketing de Turismo: teoria e prática. Rio de Janeiro: Camus, 2002.
} 
Apesar da complexibilidade desse estudo, existe um conjunto de fatores que afetam a demanda turística:

\section{Os fatores socioeconômicos condicionantes da distribuição da demanda:} visa analisar a clássica segmentação do mercado turístico (sexo, idade, país, renda, educação e outros) levando em consideração as motivações que levam o turista viajar. Neste sentido, estuda a combinação da participação turística ligada aos fatores "tempo e espaço" - tempo programado, acessibilidade, distribuição nos espaços. Nesse caso, os fatores considerados análise são: a população e a estrutura por idades; a urbanização; a demanda mundial do turismo; a demanda de turismo no Brasil; a duração do tempo livre e a renda e a educação.

Os fatores espaciais condicionantes da distribuição da demanda: surge da abordagem adotada por Defert $^{12}$, o qual defende que o tempo e o espaço são condicionantes para a análise de qualquer fenômeno gerado pela atividade do homem. $\mathrm{O}$ deslocamento é característica primordial do turismo, refletida na necessidade do homem em buscar novos espaços e ampliar seu campo de ação. Assim, existem três fatores que condicionam a escolha e as circunstâncias determinantes:

1) identidade ou absoluta harmonia entre as características próprias das áreas escolhidas;

2) elevado grau de similitude, ainda que registre elementos peculiares;

3) diversidade ou contraposição notória.

Nessa perspectiva é interessante ressaltar a observação de Beni (2002):

O homem, como sujeito ativo do Turismo, baseará suas preferências em razão da existência de múltiplos elementos ou condições, que poderão ser chamados de fatores espaciais da decisão turística. A presença ou ausência destes determinará a efetivação ou não de um deslocamento. Esses fatores podem ser classificados em função de diferentes aspectos que os configuram.

Como exemplos desses fatores citam-se: praias, montanhas, paisagem (relativo ao aspecto da natureza dos recursos); limpeza e equilíbrio, degradação (relativo ao aspecto do meio ambiente); acesso fácil, difícil, proximidade, distância (relativo ao aspecto da Comunicação); ensolarada e seca (relativo ao aspecto da Climatologia); organização do território, infra-estrutura eficiente ou inadequada, equipamentos receptivos e complementares (relativo à ação do homem), entre outros.

\footnotetext{
${ }^{12}$ DEFERT, P. Pour une politique du toursime em France. Paris: Ouvriès, 1960, Collection Économie.
} 
Consumir o produto turístico torna-se um pouco complexo uma vez que não se pode ver ou tocar o produto desejado, antes da viagem. Para facilitar esse processo, algumas imagens são produzidas a partir das informações que são divulgadas por meio dos materiais publicitários, é uma tentativa de tangibilizar os produtos e os serviços turísticos.

A motivação, ensejo pelo qual o turista deseja aquele produto turístico, é o principal fator que determina sua compra ou não. Com o crescimento da atividade turística - alavancando o aumento da indústria hoteleira e gastronômica, agências de viagens, companhias aéreas e organizações turísticas - determinar a motivação dos consumidores apenas por análise da idade, renda, educação e outras informações demográficas já não é capaz de explicar o motivo da escolha do turista.

Para realmente chegar a dados que influenciam o porquê de um turista preferir um produto ou serviço no lugar do outro, é necessário pesquisar com critérios científicos o comportamento do consumidor e a estrutura de sua tomada de decisões.

A partir do momento que o turista resolver fazer uma viagem, ele terá que optar entre diversas alternativas. São múltiplos os tipos aproximados de decisões de compra, sendo os mais utilizados:

A decisão da compra de rotina: ocorre quando o turista já possui conhecimento dos produtos que deseja consumir e decide rapidamente qual irá consumir.

O extenso processo na decisão de compra: ocorre quando as informações que o turista possui a respeito do que irá consumir são insuficientes, fazendo com que ele recorra a comunicação para obter ajuda. Nesse processo, o agente de turismo, operadoras turísticas, programas especializados em Turismo e o Marketing Turístico possuem grande relevância para sua tomada de decisão.

Os fatores psicológicos também possuem forte poder de influência nos consumidores. Isso ocorre porque entram na decisão do turista os seguintes fatores:

A percepção é a faculdade que os indivíduos têm de selecionar, organizar e interpretar as informações e criar quadros do mundo exterior;

O aprendizado as experiências anteriores terão forte poder de influência em relação à conduta atual do turista;

A personalidade são as características de cada pessoa, as quais serão refletidas nas suas tomadas de decisão; 
Os motivos são as razões, as necessidades e desejos que levam o turista a viajar. Segundo Maslow ${ }^{13}$, são as necessidades humanas básicas que impelem as pessoas a viajarem, como: necessidades fisiológicas - sol, praia, ar puro, alimentação, sexo e outras; necessidades de proteção - segurança, estabilidade, ordem; as necessidades de amor - identificação, afeto por amigos e familiares e as necessidades de auto-estima prestígio, êxito, respeito e outras;

As atitudes são as predisposições que os indivíduos têm ao avaliar determinados objetos, lugares e pessoas. Sendo estas possíveis a influências de estímulos de marketing.

Os fatores estimulantes também possuem um forte poder de influência na tomada de decisão dos indivíduos. O tamanho, a cor, o movimento, os sons são caracterizados como elementos capazes de persuasão no processo de decisão da compra.

As diversas opções de atrações, seja numa destinação turística ou até mesmo num hotel, contribuem de maneira significativa para a escolha do turista. A combinação de cores, música, natureza, belas paisagens, aumentam o desejo de consumo.

Outros fatores notórios de comentários são os fatores pessoais, sejam psicológicos ou sociológicos - posição social, as necessidades e as expectativas dos consumidores - que também exercem grande influência no processo de decisão de compra.

\subsection{MARKETING}

O marketing é a área do conhecimento que engloba todas as atividades concernentes às relações de troca, orientadas para satisfação dos desejos e necessidades dos consumidores, visando alcançar determinados objetivos de empresas ou indivíduos e consideram sempre o meio ambiente de atuação e o impacto que essas relações causam no bem estar da sociedade.

A evolução do mundo está sendo muito rápida, e as empresas não podem ficar de fora. João Festozo ${ }^{14}$, em seu livro Ciclo do Sucesso, diz:

Se sua meta diz respeito à empresa o que deve sempre lembrar que a razão de tudo se resume em uma só palavra CLIENTE, você deve se prepara para encantá-lo, satisfazer os desejos que espera, ver se esta

\footnotetext{
${ }^{13}$ MASLOW, F.L. A theory of human motivation. Phychological Review, v.50, 1943.

${ }^{14}$ FESTOZO, João. O ciclo do sucesso. São Paulo: Planeta, 2007.
} 
dentro das suas necessidades e passar tudo com muita emoção e lhe dando a atenção que espera.

A citação se refere o quanto é importante os profissionais utilizarem às ferramentas de Marketing desde o momento da oferta para atrair, consolidar e manter um cliente fiel a determinada empresa, no momento de adquirir um produto.

\subsubsection{Orientação para marketing}

Essa abordagem depende da compreensão das reais necessidades e desejos dos clientes e como construir produtos e serviços para satisfazê-los. Dessa forma, os profissionais de marketing podem criar lealdade e competir de forma eficiente com outros profissionais. Os concorrentes entram no mercado e eles respondem criando alternativas criativas e inovadoras para melhor atender as necessidades e os desejos dos clientes. O sistema de informações e avanços tecnológicos propicia uma ferramenta parceira do marketing.

A orientação para o marketing enfatiza a importância de desenvolver e comercializar produtos e serviços com base nas necessidades e desejos dos clientes.

\section{Princípios de marketing}

A literatura destaca como princípios do marketing: a concentração nas atividades que criam e fornecem valor para o cliente; a oferta um valor superior aos clientes com relação às opções da concorrência; a mudança do ambiente para melhorar as chances de sucesso; o uso das equipes interfuncionais quando elas melhorarem a eficiência e a eficácia das atividades de marketing; a consideração ao impacto das atividades de marketing sobre outros públicos interessados na organização (stakeholders: são indivíduos e grupos que também têm interesse na consequiência das decisões de marketing e podem influenciá-las - concorrentes, proprietários, fornecedores, financiadores, órgãos governamentais, funcionários e comunidades locais).

O ambiente de marketing se refere à prática da manutenção do controle das mudanças externas - forças econômicas, políticas e legais, sociais, naturais, tecnológicas e competitivas. Algumas organizações têm um programa formal de exame ambiental que procura informações relevantes em jornais, revistas e publicações profissionais/técnicas. Essas organizações procuram tendências que ofereçam 
oportunidades para novos produtos e serviços. Os profissionais de marketing podem buscar mudanças fazendo perguntas referentes a comportamento social, questões econômicas, regulamentações, tendências culturais e aspectos econômicos. Acima de tudo, eles devem ampliar sua abordagem para além de um único país e de um único mercado e adotar uma visão global do ambiente externo.

Nesse contexto, destacam-se os ambientes econômico, social, tecnológico e competitivo.

O ambiente econômico para o marketing compreende a economia de uma forma geral, incluindo ciclos de negócios, renda dos consumidores e padrões de gastos. Um ciclo de negócios é o padrão do nível de atividade econômica. A atividade econômica pode passar da prosperidade à recessão e à recuperação.

A renda do consumidor refere-se à receita individual ou familiar e pode ser medida em termos de renda bruta, renda disponível e renda discricionária. Durante tempos de prosperidade, os consumidores têm mais renda para gastar. Porém, numa recessão muitos consumidores dispõem de menos renda para comprar bens e serviços, por causa das altas taxas de desemprego e de juros.

Os padrões de gastos são influenciados não só pelos estágios de um ciclo de negócios, mas também pela disponibilidade de recursos. Quando a demanda excede a oferta de certos recursos, os consumidores não têm como gastar sua renda nesses produtos.

O ambiente social é constituído pelas pessoas de uma sociedade e seus valores, crenças e comportamentos. Os profissionais de marketing descrevem esse ambiente de acordo com a identificação das pessoas (idade, cidade.) e com as características de suas culturas. Mudanças no ambiente social, sejam elas sutis ou drásticas, podem apresentar aos profissionais de marketing novas oportunidades e desafios. Os valores culturais afetam o marketing de várias maneiras. Por exemplo, diferentes culturas dão ênfases variadas à importância da família e de um chefe de família do sexo masculino. Diferentes culturas e grupos étnicos têm fortes vínculos e preferências por certos tipos de alimentos. Alguns grupos étnicos dão um grande valor a cerimônias religiosas e culturais que foram transportadas de países da Europa, Ásia, etc.

Todos esses fatores afetam os produtos e como eles são promovidos. Por exemplo, profissionais de marketing com produtos voltados para asiáticos-americanos 
devem ser sensíveis à forte reverência pelos mais velhos na família. Assim, as pessoas idosas devem sempre ser representadas com dignidade, já que exercem tanta influência no processo de tomada de decisões em anúncios voltados a esse público. A responsabilidade social é o melhor interesse da organização no longo prazo. Muitas organizações encerram atividades negativas ou tomam ações positivas numa tentativa de beneficiar a comunidade, como aumentar as relações com os clientes e reforçar a imagem positiva. Os clientes potenciais tendem a comprar de empresas que estão preocupadas com seu bem-estar. Quando uma organização opera em mais de um país, é necessário identificar as necessidades e expectativas de diferentes comunidades a fim de oferecer-lhes valor. Empresas como a Alcoa e a IBM contribuem com obras de caridade em outros países.

O ambiente tecnológico do marketing constitui conhecimento científico, pesquisa, invenções e inovações que resultem em bens e serviços novos ou aperfeiçoados. O desenvolvimento tecnológico proporciona não somente oportunidades importantes para melhorar o valor oferecido aos clientes, como também para satisfazer suas necessidades. Os profissionais de marketing usam a tecnologia para melhorar a qualidade dos produtos e serviços oferecidos pelas organizações atuais. Avanços em tecnologia da produção, distribuição, técnicas de preços e pesquisa de marketing ajudam as organizações a servir melhor seus clientes. Mais recentemente, a Internet - uma extensa rede global de computadores em órgãos governamentais, universidades, empresas e provedores de acesso - encurtou ainda mais a distância entre os profissionais de marketing, os fornecedores e os clientes. Ela permite que as empresas construam ligações com seus mercados e membros de canais de distribuição a um custo baixo.

O ambiente competitivo compreende aos profissionais descobrir quem são seus concorrentes, ou seja, quem são aqueles fornecedores que oferecem o mesmo produto ou serviço que sua empresa oferece. A concorrência é um fator extremamente relevante na análise do ambiente externo, pois representa a ameaça de produtos substitutos, poder de barganha dos compradores e fornecedores e cria a rivalidade entre fornecedores já existentes.

Também relata que o ambiente de marketing se divide em macroambiente (ambiente externo) e microambiente (ambiente interno): 


\section{Quadro 1:composição de um ambiente de marketing - Ambiente interno:}

\begin{tabular}{|l|l|}
\hline Forças & Fraquezas \\
\hline Recursos financeiros & Falta de direção estratégica \\
\hline Marcas bem conhecidas & Altos recursos \\
\hline Habilidades tecnológicas & Instalações obsoletas \\
\hline
\end{tabular}

Fonte: LAS CASAS, Alexandre Luzzi. 2004.

\section{Quadro 2:composição de um ambiente de marketing - Ambiente externo:}

\begin{tabular}{|l|l|}
\hline \multicolumn{1}{|c|}{ Oportunidades } & \multicolumn{1}{c|}{ Ameaças } \\
\hline Novos mercados potenciais & Nova concorrência \\
\hline $\begin{array}{l}\text { Queda de barreiras comerciais } \\
\text { internacionais }\end{array}$ & Novas regulamentações \\
\hline Novos produtos potenciais & Crescimento lento do mercado \\
\hline
\end{tabular}

Fonte: LAS CASAS, Alexandre Luzzi. 2004.

A composição de uma operação de marketing se relaciona à combinação de ferramentas estratégicas usadas para criar valor para os clientes e alcançar os objetivos da organização. Há quatro ferramentas ou elementos primários no composto de marketing: preço, produto, praça e promoção.

Produto: refere-se a qualquer coisa que possa ser oferecida a um mercado para aquisição, uso ou consumo, e que possa satisfazer a um desejo ou necessidade.

\section{Quadro 3: Tipos de produtos}

\begin{tabular}{|l|l|}
\hline \multicolumn{1}{|c|}{ Tangíveis } & \multicolumn{1}{c|}{ Intangíveis } \\
\hline Bens duráveis & Serviços \\
\hline Bens não-duráveis & Pessoas \\
\hline & Locais \\
\hline & Organizações e idéias \\
\hline
\end{tabular}

Fonte: LAS CASAS, Alexandre Luzzi. 2004.

\section{Ciclo de vida do produto:}

O ciclo de vida do produto compreende os estágios que são suscetíveis a qualquer produto ou serviço. O profissional de marketing define estratégias que driblam às oscilações do mercado. Assim como o produto, o marketing tem um ciclo onde as organizações não investem somente no lançamento, mas principalmente na busca de 
ascensão ao meio do acirrado mercado atual. O composto de Marketing também é conhecido como Marketing Mix ou Mixe de Marketing.

Preço: refere-se à quantidade em reais ou outros recursos, que baliza o valor de determinado produto ou serviço através de seus custos de produção e margem de lucro estipulada, que é ofertado pela empresa e confirmado pelas forças de demanda do mercado. A decisão do preço é uma forte estratégica de marketing, pois posicionará o produto no mercado para classes e faixas etárias.

Praça (ponto de distribuição): Os canais de distribuição referem-se como produtos e serviços são entregues aos mercados para se tornarem disponíveis para trocas. A escolha de locais e pontos-de-venda é uma decisão estrategicamente planejada e requer muita cautela.

Promoção (comunicação): Referem-se como os profissionais de marketing informam, convencem e lembram os clientes sobre produtos e serviços. Refere-se à comunicação integrada de marketing, propaganda, promoção de vendas e publicidade. Oferece também uma visão geral de vendas pessoais e técnicas de vendas.

São diversas as Ferramentas de Promoção e Comunicação: Propaganda, Publicidade, Relações Públicas, Venda Pessoal, Marketing Direto, Promoções e Merchandising:

Fatores que afetam o processo decisório do mix de promoção e comunicação

Ao dar início ao planejamento estratégico de comunicação, os tomadores de decisão devem decidir o grau de ênfase que colocarão em cada área do mix. As influências principais são as características do mercado, do produto, da empresa e do sistema de distribuição:

Características do mercado: As características do mercado em que ocorrerá a comunicação são um importante fator a influenciar o processo decisório. Com relação às decisões estratégicas do mix de comunicação, há três fatores influenciadores: tipo de consumidor, considerações geográficas e concorrência.

- Tipo de consumidor: As empresas trabalham com três grupos básicos de consumidores: os domésticos, os empresariais e os intermediários, onde cada qual determina a adoção de ferramentas diferentes do mix de comunicação. Os compradores 
empresariais e intermediários são os mais bem informados quanto a preço e assistência, já para atingir o comprador doméstico pode ser necessário usar uma combinação de propaganda e venda pessoal.

- Considerações geográficas: Duas considerações geográficas básicas podem influenciar o mix de comunicação: concentração do mercado e amplitude do mercado.

- Concorrência: As estratégias da concorrência devem ser acompanhadas como uma questão de boa prática de negócios, ligada à observação do meio ambiente.

Características do produto: Um aspecto fundamental do processo decisório do mix de comunicação é o produto ou serviço que está sendo comunicado pela empresa.Uma das considerações mais informativas para se determinar o peso de cada variável do mix de comunicação é a categoria de produto do item. A discussão sobre ciclo de vida de produto, todo produto passa por diversos estágios de desenvolvimento no mercado

- A prática comercial anterior: Esse é o fator de inércia. Algumas empresas ficam estáticas no hábito de fazer a mesma coisa ano após ano, independentemente de o hábito ser ou não justificável.

- Fundos disponíveis: O orçamento disponível para comunicação pode determinar a adoção da venda pessoal; o que pode parecer contraditório, uma vez que a venda pessoal foi citada anteriormente como menos eficiente do que a propaganda.

- Tamanho da equipe de vendas.

- Extensão da linha de produtos: Quando a empresa possui uma linha de produto ampla e profunda, a natureza do mix de comunicação sofre várias mudanças.

Características do sistema de distribuição: As estratégias de marketing mix relacionadas ao sistema de distribuição têm influência direta sobre o mix de comunicação. Três tipos de decisão de distribuição afetam a configuração do mix: a intensidade da distribuição, a extensão do canal e o tipo de intermediário.

- Intensidade de distribuição: O número total de distribuidores e varejistas do produto afeta à definição da estratégia de comunicação.

- Extensão do canal: A extensão do canal refere-se ao número de níveis de distribuição por onde um produto passa até chegar ao usuário final. Se o canal for extenso as empresas passam a necessitar de um maior controle sobre os distribuidores, 
atacadistas e varejistas, e desenvolver mais sua equipe de vendas para ajudar a gerenciar, A estratégia para o canal curto, que distribui o produto diretamente para o usuário final, adotará a técnica de venda pessoal ou de marketing direto.

- Tipos de intermediários: Os tipos de distribuidores, atacadistas e varejistas usados no canal modificam a estratégia de comunicação. 


\section{AS PARCERIAS DO "PROJETO MOVIMENTO DE VALORIZAÇÃO DA GASTRONOMIA BRASILEIRA NO EXTERIOR” PARA PROMOÇÃO DO TURISMO BRASILEIRO NO EXTERIOR}

Por tratar-se de um Estudo de Caso, referente a uma ação específica da EMBRATUR, o qual será demonstrado onde e como foi idealizado o presente trabalho.

\subsection{INSTITUTO BRASILEIRO DE TURISMO - EMBRATUR}

A EMBRATUR foi criada como Empresa Brasileira de Turismo, com natureza de Empresa Pública, pelo artigo 11 do Decreto-Lei no 55, de 18 de novembro de 1966, vinculada ao antigo Ministério da Indústria e do Comércio, com a finalidade de incrementar o desenvolvimento da indústria do turismo e executar, no âmbito nacional, as diretrizes que lhes foram traçadas pelo governo. Foi a primeira empresa pública criada no Brasil.

Antes da criação da EMBRATUR, a coordenação das atividades de turismo era feita pela Divisão de Turismo e Certames do antigo Ministério da Indústria e Comércio.

Durante os seus primeiros anos, a EMBRATUR cuidou da elaboração e sistematização das normas para aplicação de incentivos fiscais, registro e fiscalização das agências de viagens.

No começo da década de 1970, o chamado milagre econômico, com taxas mais altas de crescimento do Produto Interno Bruto e baixa taxa de inflação, mostra um cenário promissor para o turismo brasileiro.

A partir da metade da década de 1970, a EMBRATUR e o trade (empresas e entidades prestadoras de serviços turísticos) nacional começam a participar de eventos Internacionais de Turismo com a finalidade de divulgar o país.

Com a edição da Lei $n^{\circ}$ 8.181, de 28/03/1991, mudou-se a denominação de Empresa Brasileira de Turismo para EMBRATUR - Instituto Brasileiro de Turismo, autarquia vinculada à antiga Secretaria de Desenvolvimento Regional da Presidência da República, tendo por finalidade apoiar a formulação, coordenação e implementação da política nacional de turismo, como fator de desenvolvimento social e econômico.

Devido a globalização, ocorreram mudanças no mercado mundial de turismo.

Com a criação do Ministério do Turismo, em 2003, a formulação, coordenação e a implementação da política de turismo passaram a ser responsabilidade daquele Ministério, ficando a EMBRATUR responsável pelo apoio à formulação, coordenação e 
implementação da Política Nacional de Turismo. Reconhece-se, então, a importância do turismo como um setor estratégico da economia brasileira.

A segmentação do turismo é uma estratégia de marketing inovadora para sua divulgação e abre oportunidades para o setor. A atividade turística se desenvolve num cenário positivo. O país ocupa lugar de destaque no cenário internacional, ao levantar a necessidade de discussões estratégicas, tais como o fim da fome e da pobreza e a valorização da diversidade cultural, do desenvolvimento sustentável e da paz.

Atualmente, a EMBRATUR tem a seguinte Estrutura Organizacional:

Figura 2 - Estrutura Organizacional da EMBRATUR

EMBRATUR

INSTITUTO BRASILEIRO DE TURISMO PRESIDÊNCIA

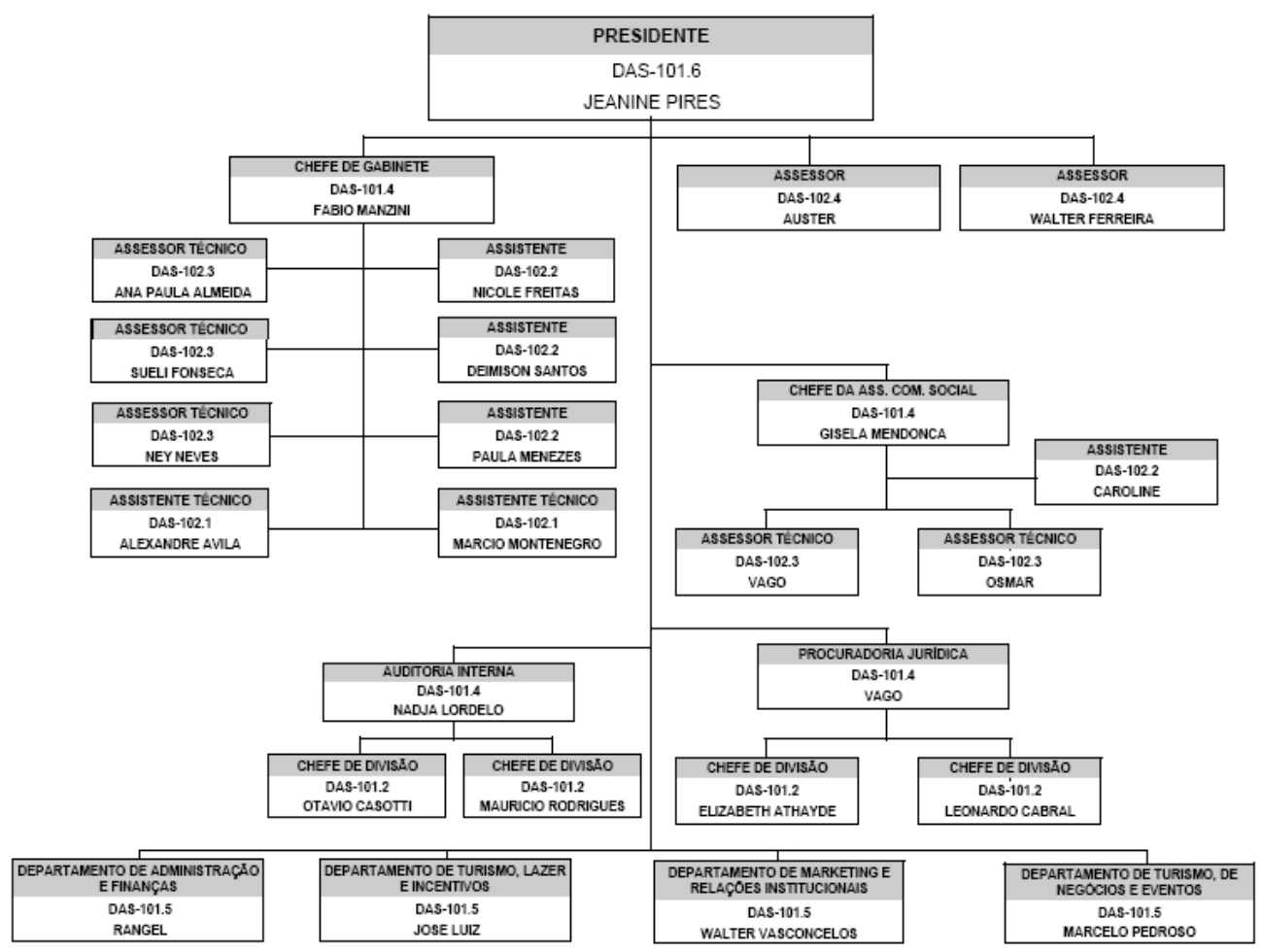

Fonte: http://www.turismo.gov.br 


\subsection{O PLANO AQUARELA}

Em 2004, foi iniciada a elaboração do Plano Aquarela - Marketing Turístico Internacional, cujos objetivos foram impulsionar o turismo internacional no Brasil, incrementando o número de turistas estrangeiros no país e a conseqüente ampliação de entrada de divisas.

O Plano Aquarela foi elaborado no momento em que o governo brasileiro iniciava a implantação de mudanças estratégicas no seu sistema de gestão do turismo. Com a criação do Ministério do Turismo e uma nova estrutura de gerenciamento, a EMBRATUR passava a dedicar-se exclusivamente à promoção do turismo no exterior.

Essa mudança de foco requereu da EMBRATUR uma atuação profissional e direcionada a atender às necessidades e os desejos do mercado internacional. Dessa forma, o Plano Aquarela enquadrou-se no Plano Nacional de Turismo 2003 - 2007 , em que o Ministério do Turismo estabeleceu seus objetivos e metas de trabalho.

\section{Figura 3 - Organograma do Plano Aquarela}

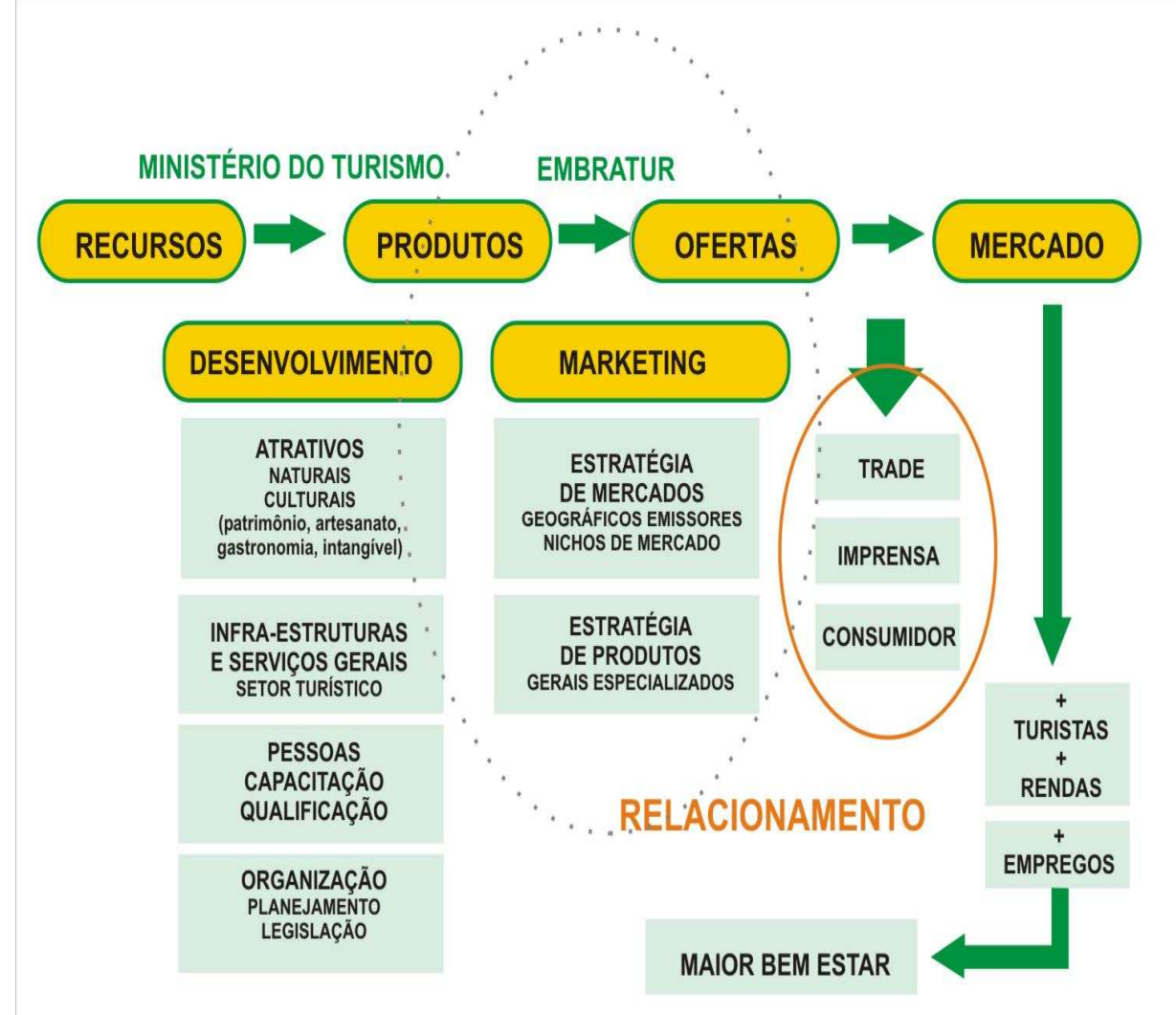

Fonte: http://www.turismo.gov.br 
A implantação do Plano iniciou-se a partir de março de 2005, com uma nova abordagem direcionada aos mercados prioritários. O Plano Aquarela é um programa com planejamento de longo prazo que já apresenta resultados com o aumento da receita da conta turismo da balança ${ }^{15}$ de pagamentos, apesar do saldo sempre negativo a exceção dos anos de 2003 e 2004, devido às despesas dos turistas brasileiros em viagem ao exterior.

A definição do conceito do Plano Aquarela, segundo a Chias Marketing ${ }^{16}$, empresa contratada para elaboração, é:

O Plano Aquarela - Marketing Turístico Internacional do Brasil é o instrumento técnico adequado para alcançar o objetivo de impulsionar o turismo. Em sua formulação foi considerado um trabalho técnico de implantação a ser realizado para que este crescimento turístico seja sólido e sustentável, a partir de um processo de planejamento que vai diferenciar o Planejamento para o Desenvolvimento Turístico do Planejamento para o Marketing Turístico, a fim de que se tenha claro qual é o âmbito dentro do qual o trabalho foi elaborado.

Para dar forma ao Plano Aquarela foi utilizado um esquema metodológico pensado para conjugar a liderança institucional do Ministério do Turismo, através da EMBRATUR, com a perícia técnica, o que permitiu um trabalho rigoroso, ordenado, participativo e de busca de consenso e compromisso por parte dos agentes públicos e privados do setor.

Desenhada e implantada a partir de 2005, a Marca Brasil serve de referência mandatária para todo o material gráfico produzido para as ações promocionais. A marca hoje já tem sua presença em toda a promoção para o trade internacional do turismo e também foi adotado pela APEX-BRASIL (Agência de Promoção de Exportações e Investimentos), e está estampada em milhares de produtos de exportação brasileiros.

Em relação ao trabalho em questão e a Marca Brasil, vale ressaltar que a cor vermelha representa as Festas Populares, onde a cultura e consequentemente a gastronomia estão incluídas.

\footnotetext{
${ }^{15}$ A conta de turismo é uma rubrica contábil existente na Balança de Pagamentos de um país, no sub item Balanço de serviços e que mensura a quantidade de turistas que entram em um determinado país para usufruir dos serviços turísticos por ele prestados. No caso, quando essa rubrica é positiva, significa que no ano houve uma entrada positiva de turistas em relação a residentes que viajaram para outro país.

${ }^{16}$ PLANO AQUARELA DO BRASIL. Marketing Turístico Internacional. Relatório executivo, 2005.
} 
Figura 4 - Marca Brasil

Festas populares

Chul mar

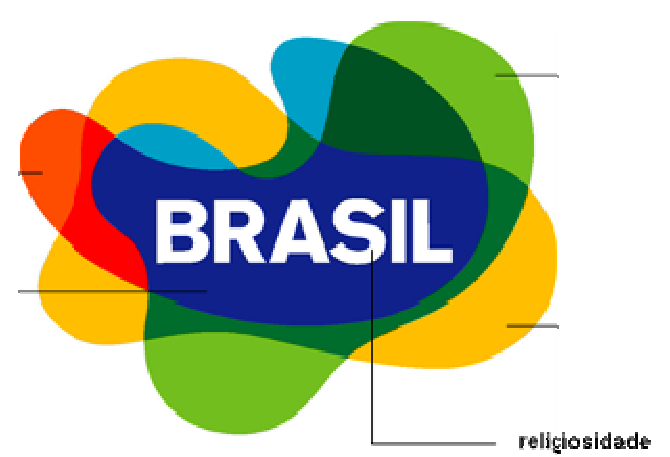

Florestas

Soll luminosidads

Sensational!

Fonte: http://www.turismo.gov.br

Foram mapeados os mercados-alvos, indicados os produtos a serem trabalhados em cada mercado, definidas as prioridades na alocação e o volume de recursos: hoje o Plano Aquarela está passando por uma fase de readequação em razão das necessidades para o desenvolvimento do turismo brasileiro, bem como em relação às necessidades emanadas pelos turistas ao redor do mundo, mas principalmente pelas mudanças conjunturais como crises, epidemias, economia, etc.

Conforme demonstrado na figura de n. ${ }^{\circ} 5$ - Países Prioritários para promoção do Brasil, nota-se que o Chile está colocado na $3^{\mathrm{a}}$ posição, dentro do Quadro mercados prioritários, como um país de altíssima prioridade para a promoção do Brasil. 
Figura 5 - Países prioritários para promoção do Brasil - Chile $3^{\circ}$ país/altíssima prioridade

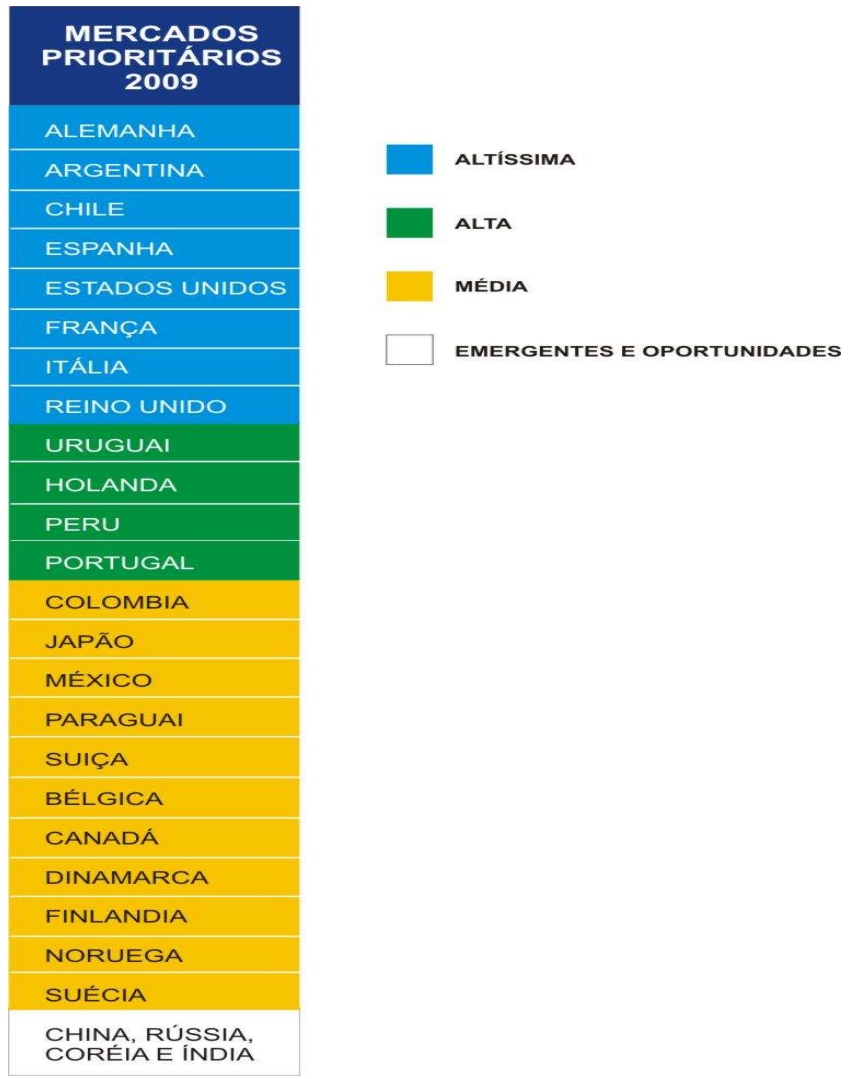

Fonte: http://www.turismo.gov.br

Foi pensando não apenas nos novos destinos a serem ofertados conforme o Programa de Regionalização (65 Destinos Indutores de Turismo de Desenvolvimento de Turismo), mas principalmente na oferta de novos predicados que o Brasil tem como referências históricas e culturais de nosso povo que o Ministério do Turismo, por meio da EMBRATUR, vem investindo na venda de novos produtos e, dessa forma, formalizou um dos inúmeros instrumentos utilizando como ferramenta para promoção a gastronomia, em países de interesses para o Brasil.

Programa de Regionalização é um Programa do Governo Federal, executado pelo Ministério do Turismo que tem como meta principal, qualificar os destinos Brasileiros para competir internacionalmente.

Atrair turistas estrangeiros de alto poder aquisitivo, interessados em conhecer mais do que belas paisagens. Esse é o objetivo do Ministério do Turismo, por meio da EMBRATUR, ao colocar a gastronomia como um dos grandes atrativos da promoção internacional do turismo brasileiro Não basta divulgar a nossa rica gastronomia, 
repleta de sabores, cheiros e cores. Para seduzir o turista estrangeiro pelo estômago é preciso mais: a apresentação dos pratos, o modo de preparo e a qualidade dos ingredientes, diferenciais que podem garantir a satisfação daqueles que valorizam os prazeres de uma boa refeição.

A crescente preocupação com a qualidade dos serviços se justifica plenamente: pesquisa encomendada pela EMBRATUR e realizada pela Vox Populi (2006) mostra que $10 \%$ dos visitantes estrangeiros declararam que a gastronomia brasileira é o que o país tem de mais positivo, demonstrando o potencial que a comida das mais diversas regiões do Brasil traz para o turismo.

“O nosso país tem belezas naturais incomparáveis, mas pode oferecer muito mais. Não tenho dúvidas de que a rica e diversificada gastronomia brasileira é um dos grandes diferenciais que o Brasil pode oferecer ao visitante estrangeiro que busca algo além de sol e praia", acredita a presidente da EMBRATUR, Jeanine Pires, no Clipping EMBRATUR (2008).

É por isso que a EMBRATUR investe de forma constante na promoção da gastronomia brasileira, levando chefs renomados para feiras internacionais ao redor do mundo, promovendo degustação de comidas e bebidas nacionais, e apoiando a iniciativa dos estados em apresentar a culinária regional em eventos em outros países.

Isto posto, foram aportados recursos para a promoção do Brasil por meio do Projeto Movimento de Valorização da Gastronomia Brasileira no Exterior, que realizou uma série de ações no sentido da divulgação do Brasil e de sua gastronomia em outros países, como o evento "Estrelas da Gastronomia".

\subsection{PROJETO MOVIMENTO DE VALORIZAÇÃO DA GASTRONOMIA BRASILEIRA NO EXTERIOR}

O Projeto Movimento de Valorização da Gastronomia Brasileira no Exterior se constitui numa expressão de identidade cultural como valor agregado ao diferencial competitivo do turismo brasileiro, e apresentou, em seu projeto básico, os seguintes objetivos:

- Realizar 05 eventos gastronômicos em diferentes países (Espanha, Estados Unidos, Inglaterra, França e Chile);

- Participar de 01 feira internacional (SIAL) em Paris - França;

- Divulgar a riqueza gastronômica do Brasil no exterior; 
- Promover a gastronomia brasileira como diferencial competitivo para o turismo;

- Valorizar a imagem da ABRASEL, da Embratur e demais parceiros envolvidos.

Uma das ações desse Projeto é o "Estrelas da Gastronomia", que se constitui numa programação de eventos em cidades escolhidas previamente por meio de visita técnica, onde foram identificados restaurantes com identidade brasileira, com o objetivo de apresentar aos seus freqüentadores (turistas em potencial) a gastronomia e a música brasileiras, apresentando e promovendo os destinos turísticos brasileiros correlatos.

No período de 2004 a 2006, os festivais gastronômicos vêm se consolidando como um movimento e fortalecendo de maneira significativa a gastronomia brasileira. Dentre outras importantes iniciativas, nestes últimos dois anos, foram realizadas as seguintes ações:

- Realização do maior Festival Gastronômico do planeta - Brasil Sabor;

- Realização da maior mostra gastronômica já realizada com pratos brasileiros, durante as duas edições do Salão de Turismo, com mais de 50 mil degustações de pratos de todo o Brasil;

- Participação em feiras e congressos com estande que demonstraram e valorizaram a gastronomia brasileira;

- Estímulo a centenas de chefes e cozinheiros para a utilização de ingredientes brasileiros nas suas receitas;

- Realização de programas de qualificação para o setor no Brasil de segurança dos alimentos, atendimento e gestão;

- Participação de uma mostra gastronômica na sede da ONU em Nova Iorque, com envolvimento de chefes brasileiros renomados e atingindo todos os recordes de degustações;

- Publicação de livros, roteiros gastronômicos e do primeiro tradutor gastronômico;

- Realização de degustações e mostras gastronômicas em diversos estados brasileiros. 
Dessa forma, foi fundamental que as ações de valorização da gastronomia nacional fossem ampliadas em outros países como expressão de identidade cultural e diferencial competitivo para o turismo brasileiro.

A partir dessa percepção da gastronomia brasileira como diferencial competitivo para o turismo, que levou a EMBRATUR a conveniar com a ABRASEL - Associação Brasileira de Bares e Restaurantes um projeto para estimular a criação de um movimento para a valorização da gastronomia no exterior.

A EMBRATUR como Autarquia recebe orçamento federal, entretanto, não tem em seu corpo funcional servidores especialistas na área de gastronomia para desenvolver, coordenar e executar algumas de suas ações no exterior. Por isso, utilizou do instrumento legal convênio para executar essas ações. A legislação que regula o ato é a IN 01/97 e a Portaria nº. 127/08 do Ministério do Planejamento, Orçamento e Gestão. 


\section{RESULTADOS E DISCUSSÃO}

\subsection{ANÁLISE AMBIENTAL DO EVENTO}

\subsection{Pontes Fortes e Fracos:}

Após a participação no "Estrelas da Gastronomia" em Santiago, no Chile, diante dos pontos fortes e fracos, faz-se mister verificar se sua realização pode ou não ser validada, ou seja, se correspondeu às expectativas.

Não há como se verificar, se, de fato, a gastronomia agregou valor aos produtos ofertados nos mercados de Santiago - Chile. É possível afirmar, apenas, que foram divulgadas amostras reais dos sabores brasileiros, bem como dos destinos sem, contudo, medir o verdadeiro impulso dado à transformação de turistas potenciais em reais. Isso significa que, na prática, não há como saber se a divulgação promovida acarretou ou não aumento da procura do Brasil como roteiro turístico..

Vale ressaltar que um bom processo de gestão, tanto com relação ao evento, como das estratégicas políticas mais amplas, devem necessariamente incluir uma avaliação/instrumentos de mensuração que permitam analisar se os resultados alcançados foram os desejáveis ou não.

\subsection{CRITÉRIOS DEFINIDOS NOS OBJETIVOS DO PROJETO}

\section{A - quantitativos}

O executor do projeto foi a ABRASEL, convenente, que tinha como período para a execução de dezembro de 2007 a dezembro de 2008. O evento de que trata o presente estudo, por sua vez, ocorreu do dia primeiro ao dia 08 de dezembro de 2008.

Vale destacar que a análise propriamente dita, se deu em um único dia, ou seja dia da participação do jantar. Neste dia foram colhidas informações necessárias para a elaboração do estudo, bem como vivenciar a ação em comento, onde foram tiradas fotos, degustados alguns pratos, e ainda, feitas entrevistas (conversa direta) com os participantes, sem elaboração prévia de quaisquer instrumentos.

A ação ocorreu, porém não houve um planejamento adequado na execução do evento no que concerne ao dia de realização (uma segunda-feira, dia em que tradicionalmente os chilenos não se dispõem a sair de casa), quantitativo do público alvo formador de opinião para a imagem do Brasil (presença de poucos convidados), pois o tempo foi exíguo entre a entrega do convite e a realização do jantar. 


\section{B - qualitativos}

A apresentação da gastronomia brasileira foi feita por meio de diversos pratos elaborados com ingredientes tipicamente brasileiros. Desde o coquetel de frutas à base de goiaba e manga, passando pela entrada de sopa fria de palmito, segundo prato camarão servido no abacaxi ao molho de gengibre, prato principal à base de filé ao molho de olho de castanhas de caju, até a sobremesa criada, composta por goiaba, tortelete de banana, chocolate e outros ingredientes, bem como a presença de um músico tocando música brasileira.

Vale ressaltar, todavia, que a sobremesa denominada "Cartola mineira" servida no jantar, teve sua receita e, inclusive, ingredientes, renovada. De acordo com Cavalcanti (2009), o prato "é uma das mais tradicionais (e saborosas) sobremesas pernambucanas", nasceu da mistura de ingredientes, técnicas, experiências e hábitos culturais do colonizador português, do índio e do escravo africano. Seu principal ingrediente é a banana. Outro ingrediente importante, contudo, é o queijo do sertão, também chamado "de queijo manteiga", que é bastante diferente do queijo usado em Minas Gerais. Daí, o prato não ter mostrado a realidade típica regional do país, conforme previsto no Projeto. Isso, obviamente, não consiste em desmerecimento do chef quanto à arte empregada na elaboração do prato.

Ressalte-se, também, que é a permanência de determinados hábitos alimentares e práticas gastronômicas que cria um panorama gastronômico com certa coerência, desenhando as chamadas cozinhas regionais. Degustar um prato típico, dessa forma, é uma maneira de antecipar a imagem do povo da qual ele é ícone. (SANTOS, 1997, p. 160).

É possível estimar que houve promoção da gastronomia brasileira como diferencial competitivo para o turismo, uma vez que os frequentadores do evento, os turistas em potencial, tiveram acesso a uma amostra do que se serve pelo país porém, poderá haver uma imagem deturpada entre os pratos servidos e em especial a sobremesa, visto que a imagem que o formador de opinião/turista em potencial poderá ter com relação à Gastronomia típica brasileira,pois foi constatada não conformidade na elaboração da sobremesa, a cartola mineira. 
Certamente a apresentação da gastronomia por meio de elementos tipicamente brasileiros foi um ponto forte para demonstrar a riqueza de nossa culinária. Somente não foi criado, ainda, um dispositivo capaz de mensurar se houve aumento nas vendas de pacotes para o Brasil a partir do evento. 


\subsection{ESTRATÉGIAS DE MARKETING UTILIZADAS PARA ATINGIR OS OBJETIVOS DO PROJETO}

\section{A - Público alvo}

O público alvo escolhido para ser divulgador do Brasil em Santiago no Chile, foram jornalistas da imprensa chilena, representantes da Embaixada e do Consulado brasileiros, equipe da EMBRATUR, Comitê Descubra Brasil, empresários, chefs de cozinha. Primeiramente, porque o evento tornou-se notícia que divulgou o produto turístico do Brasil. Em segundo lugar, porque as imagens veiculadas eram belas e, os pratos apresentados e degustados aguçaram com certeza o desejo dos participantes de conhecer o Brasil.

\section{B - Ferramentas de Marketing}

Sobre as mesas foram dispostos os displeys com fotos das regiões do Brasil, bem como totém colocado em local de destaque, o menu (pratos da culinária brasileira) e entrega de material promocional (guia) e no final do jantar os participantes receberam um brinde-avental, contendo a marca criada especialmente para a ocasião. 


\section{CONSIDERAÇÕES GERAIS}

Não é possível se estimar se, de fato, o evento promoveu os destinos nacionais por meio da gastronomia brasileira, uma vez que não se dispôs de instrumentos objetivos e específicos para a principal pergunta desse evento.

Evidentemente, os freqüentadores do evento tiveram acesso a uma amostra do que se serve pelo país, assim como o público presente era formador de opinião uma vez que a amostra foi constituída por profissionais qualificados para o fim que se destinou.

O produto ofertado aos formadores de opinião se constituiu num instrumento estratégico importante para a promoção do destino Brasil, mas mesmo assim o totém não mostrava claramente a culinária brasileira. As imagens apresentadas se referiam principalmente aos ambientes físicos - praia, ecoturismo, negócios, artesanatos, sol,

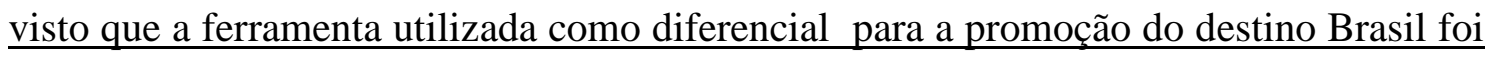
a gastronomia, deveria ter sido mais explorado os elementos utilizados nas peças promocionais, com elementos representativos da culinária brasileira.

Por fim, vale ressaltar que o objetivo maior do estudo foi investigar a gastronomia como atrativo cultural, porém pode-se dizer que houve uma não conformidade que poderá distorcer a imagem do que é a gastronomia típica do país como colocado no início do trabalho, baseado nas informações do projeto "Movimenta de valorização da gastronomia brasileira no exterior". Ainda, foram avaliadas às estratégias de marketing promocional, que conforme estudo, foram adequadas: totém, display, guia dos roteiros turísticos, brinde e evento regado a música brasileira.

Vale destacar que a chegada de turistas chilenos ao Brasil é um fator preponderante, pois de nada valeria a execução do evento e o gasto de recursos públicos senão fosse em busca de novos turistas. Afirmar o alcance de tal proposição, contudo, é temeroso, pois ainda não foi criado um dispositivo capaz de mensurar se houve aumento nas vendas de pacotes ao Brasil após o evento.

É fundamental a criação de estudos complementares para que se possa ter um retorno mensurável na questão da vinda de tais turistas, no intuito de provar com mais precisão que os gastos públicos no exterior para divulgar o Brasil por meio de eventos, seminários, workshops entre outros, tem gerado retornos acima do esperado, confirmando a necessidade de "road shows" nesse estilo para aumentar a demanda de turistas estrangeiros pelo destino Brasil, dinamizando assim, esse setor da economia 
brasileira que é responsável por 3,6\% do PIB, fonte IBGE - Instituto Brasileiro de Geografia e Estatística.

A Organização Mundial de Turismo recomenda que toda ação deva existir um instrumento de mensuração com relação aos impactos, sejam negativos ou positivos para que os serviços e produtos permaneçam com qualidade. Com isso, pode-se concluir que poderia ser criado um dispositivo de mensuração após evento, no sentido de averiguar se houve aumento na venda de pacotes para o Brasil a partir de estatística elaborada pelos operadores participantes do evento, num período posterior a cada evento e a cada 05 (cinco) anos haveria a decupação dos dados e com isso evitar lacunas em branco. 


\title{
REFERÊNCIAS BIBLIOGRÁFICAS
}

\begin{abstract}
APOSTILA GASTRONOMIA E SEGURANÇA ALIMENTAR MÓDULO IIHISTÓRIA DA ALIMENTAÇÃO E EMPREEENDIMENTOS GASTRONÕMICOS
\end{abstract}

BANCAL, J., L'économie des sociologues. Paris: PUF, 1974.

BARRETO, Margarita, Turismo e legado cultural: As possibilidades do planejamento. 4 ed. Campinas: Papirus, 2003. 2002 .

BENI, Mário Carlos. Análise Estrutural do Turismo. São Paulo: SENAC, Vol.1. São Paulo: SENAC, pp. 177, 2001.

\section{Como aprender e ensinar: A política do turismo.} - Construção de um modelo teórico referencial na pesquisa em turismo. São Paulo. ECA/USP, 1988, tese de doutorado.

BRASIL: Decreto-Lei $n^{\circ}$ 55. Presidência da República. Brasília: 18 de novembro de 1966. 2001.

CASCUDO, Luis da Câmara. História da Alimentação. São Paulo: Global

CAVALCANTI, Lectícia. Site 360graus.

CHURCMAN, C. West The systems approach. Nova York: Dell Publishing, 1968.

CIPPING EMBRATUR, 2008

DAMATTA, Roberto. O que faz o brasil Brasil. Rio de janeiro: Rocco, 2001.

DEFERT, P. Pour une politique du toursime em France. Paris: Ouvriès, 1960, Collection Économie.

Disponível em <http://www.folha.uol.com.br/enquete 2003> Acesso em 11 de junho de 2009.

Disponível em < http://www.turismo.gov.br> Acesso em 11 de julho de 2009. junho de

Disponível em <http://pt.wikipedia.org/wiki/Gastronomia> Acesso em 11 de 2009.

EMBRATUR. Plano Aquarela: marketing turístico internacional do Brasil. Brasília: Chias Marketing, 2005. 
FESTOZO, João. O ciclo do sucesso. São Paulo: Planeta, 2007.

GUIA QUATRO RODAS. São Paulo: Abril, 2005.

JIMMÉNEZ G., Luis Fernando. Apuntes de la cátedra sobre teoría turística. Bogotá: Universidad del Externado de Colombia, 1982.

KRIPPENDORF, Jost. Sociologia do Turismo: para uma nova compreensão do lazer e das Viagens. São Paulo: Aleph, 2001. 1998.

LAS CASAS, Alexandre Luzzi. Marketing de Serviços. São Paulo: Atlas,

CAVALCANTI, Lectícia. Site 360graus. 2004. . Marketing: conceitos, exercícios e casos. 6 ed. São Paulo: Atlas,

MARTINI, Xavier J. Elementos de análisis econômico del turismo. Buenos Aires: Turística S.R.L., 1983. 1943.

MASLOW, F.L. A theory of human motivation. Phychological Review, v.50,

MIDDLETON, Victor T. C. Marketing de Turismo: teoria e prática. Rio de Janeiro: Camus, 2002.

MINISTÉRIO DA CULTURA. Registro do Patrimônio Imaterial, 2000.

MINISTÉRIO DO TURISMO. $\mathbf{1 0}^{\circ}$ Relatório de Atividades. Brasília, dezembro de 2005 .

MINISTÉRIO DO TURISMO. Estudo de Competitividade dos 65 Destinos Indutores do Desenvolvimento Turístico Regional. Brasília: MTur, 2007. 2008 .

MINISTÉRIO DO TURISMO. Estudo de Competitividade, Relatório Brasil,

MINISTÉRIO DO TURISMO. Turismo Cultura - Orientações Básicas, 2006.

PLANO AQUARELA DO BRASIL. Marketing Turístico Internacional. Relatório executivo, 2005.

SANTOS, 1997, p. 160).

SCHLÜLTER, Regina G. Gastronomia e Turismo. São Paulo: Aleph, 2003.

SCHOMOLL, A. C. Tourisme et marketing. Madri: OMT, 1974. 
7 ANEXOS 
ANEXO A - Quadro de Pontos fortes e Pontos fracos do evento.

\begin{tabular}{|c|c|}
\hline Pontos Fortes & Pontos Fracos \\
\hline $\begin{array}{l}\text { Excelente qualidade dos pratos } \\
\text { oferecidos no jantar, bem como divulgação de } \\
\text { produtos tipicamente brasileiros; } \\
\text { Disponibilização de recursos } \\
\text { financeiros, devidamente justificados, em rubrica } \\
\text { própria para o desenvolvimento da ação; } \\
\text { Quantidade suficiente de pessoal } \\
\text { especializado, como: relações públicas, garçom, } \\
\text { chef de cozinha e demais auxiliares, além de } \\
\text { serem estes profissionais capacitados para o } \\
\text { desenvolvimento do trabalho. } \\
\text { Material promocional adequado à } \\
\text { ação: displey de mesa, totem, guia com as regiões } \\
\text { do Brasil, DVD, brinde (avental), certificado aos } \\
\text { participantes da parceria. }\end{array}$ & $\begin{array}{l}\text { Número de participantes menor do que o } \\
\text { esperado; } \\
\text { Realização do evento em dia não } \\
\text { favorável: segunda-feira; } \\
\text { Insuficiência de outros dispositivos para } \\
\text { a promoção do produto BRASIL. } \\
\text { Inexistência de mensuração da ação, em } \\
\text { relação aos turistas que vêem ao Brasil. } \\
\text { Modificação de receita típica. } \\
\text { Falhas no planejamento. }\end{array}$ \\
\hline
\end{tabular}


ANEXO B - Quadro do cronograma de execução (meta, etapa ou fase)

\begin{tabular}{|c|c|c|c|c|c|c|}
\hline \multirow{2}{*}{ META } & \multirow{2}{*}{ ETAPA } & \multirow{2}{*}{ ESPECIFICAÇÃO } & \multicolumn{2}{|c|}{ INDICADOR FÍSICO } & \multicolumn{2}{|c|}{ DURAÇÃO } \\
\hline & & & UND. & QUANT. & INÍCIO & TÉRM. \\
\hline 4 & & $\begin{array}{l}\begin{array}{l}\text { Realização de evento gastronômico em Santiago } \\
\text { (Chile) }\end{array} \\
\end{array}$ & & & & \\
\hline & 4.1 & Locação de espaço físico & Espaço & 1 & Out/08 & Dez/08 \\
\hline & 4.2 & Serviços de coquetel/almoço/jantar & Pessoas & 60 & Out/08 & Dez/08 \\
\hline & 4.3 & Compra de insumos (bebidas, comidas) brasileiros & Unidade & 60 & Out/08 & Dez/08 \\
\hline & 4.4 & $\begin{array}{l}\text { Produção de vídeo } 45^{\prime} \text { com aplicação de textos e } \\
\text { assinaturas sobre material editado - Restaurantes } \\
\text { participantes em Santiago do Chile }\end{array}$ & Serviço & 1 & Out/08 & Dez/08 \\
\hline & 4.5 & $\begin{array}{l}\text { Produção de site - Inclusão evento em Santiago do } \\
\text { Chile }\end{array}$ & Serviço & 1 & Out/08 & Dez/08 \\
\hline & 4.6 & Serviços de relações públicas & Serviço & 1 & Out/08 & Dez/08 \\
\hline & 4.7 & Serviços de criação de material gráfico/promocional & Serviço & 1 & Out/08 & Dez/08 \\
\hline & 4.8 & Produção de material gráfico e promocional & Serviço & 1 & Out/08 & Dez/08 \\
\hline & 4.8.1 & $\begin{array}{l}\text { Totem formato } 0,50 \times 1,60 \mathrm{~m} \text {, impressos a } 4 \times 4 \text { cores, } \\
\text { em cartão duplex } 300 \mathrm{~g}\end{array}$ & Unidade & 6 & Out/08 & Dez/08 \\
\hline & 4.8.2 & $\begin{array}{l}\text { Guia - capa } 21 \times 15 \mathrm{~cm} 4 \times 4 \text { cores, papel couché fosco } \\
230 \mathrm{~g} \text {, pág formato de } 10,5 \times 15 \mathrm{~cm} 4 \times 4 \text { cores, em papel } \\
\text { couché fosco } 150 \mathrm{~g}\end{array}$ & Unidade & 5000 & Out $/ 08$ & Dez/08 \\
\hline & 4.8 .3 & $\begin{array}{l}\text { Display formato aberto de } 42 \times 13 \mathrm{~cm} \text {, impresso a } 4 \times 0 \\
\text { cores, em papel supremo } 350 \mathrm{~g} \text {, acabamento com } \\
\text { laminação fosca de um lado, vincado e colado. }\end{array}$ & Unidade & 300 & Out/08 & Dez/08 \\
\hline & 4.8.4 & $\begin{array}{l}\text { Adesivo formato de } 7 \mathrm{~cm} \text { de diâmetro, impressos a } \\
4 \mathrm{x} 0 \text { cores, em papel adesivo brilho, acabamento com } \\
\text { corte especial. }\end{array}$ & Unidade & 300 & Out/08 & Dez/08 \\
\hline & 4.8.5 & $\begin{array}{l}\text { Camisa em malha PVC c/ aplicação de transfer } \\
\text { formato } 20 \times 19 \mathrm{~cm} \text { frente }\end{array}$ & Unidade & 15 & Out/08 & Dez/08 \\
\hline & 4.8.6 & $\begin{array}{l}\text { Avental em tecido oxford c/ aplicação transfer formato } \\
17 \text { x } 16 \text { frente }\end{array}$ & Unidade & 120 & Out/08 & Dez/08 \\
\hline & 4.8.7 & $\begin{array}{l}\text { Certificado em papel CF } 230 \mathrm{gr} \text {, formato } 15 \times 30 \mathrm{~cm} 4 \\
\mathrm{x} 0 \text { cor }\end{array}$ & Unidade & 6 & Out/08 & Dez/08 \\
\hline & 4.9 & Passagem Brasil / Santiago / Brasil & $\begin{array}{l}\text { Passage } \\
\mathrm{m}\end{array}$ & 6 & Out/08 & Dez/08 \\
\hline & 4.10 & Diárias & Diária & 54 & Out/08 & Dez/08 \\
\hline & 4.11 & Serviços de divulgação & Serviço & 1 & Out/08 & Dez/08 \\
\hline & 4.12 & Serviços de remessa de material para exterior & Serviço & 1 & Out/08 & Dez/08 \\
\hline 6 & & Serviços de consultoria gastronômica & Serviço & 1 & Out/08 & Dez/08 \\
\hline 7 & & Serviços de organização de eventos & Serviço & 1 & Dez/07 & Dez/08 \\
\hline 8 & & Produção Executiva & Serviço & 1 & Dez/07 & Dez/08 \\
\hline
\end{tabular}


ANEXO C- Foto do Restaurante Acuarela (local de realização do evento)

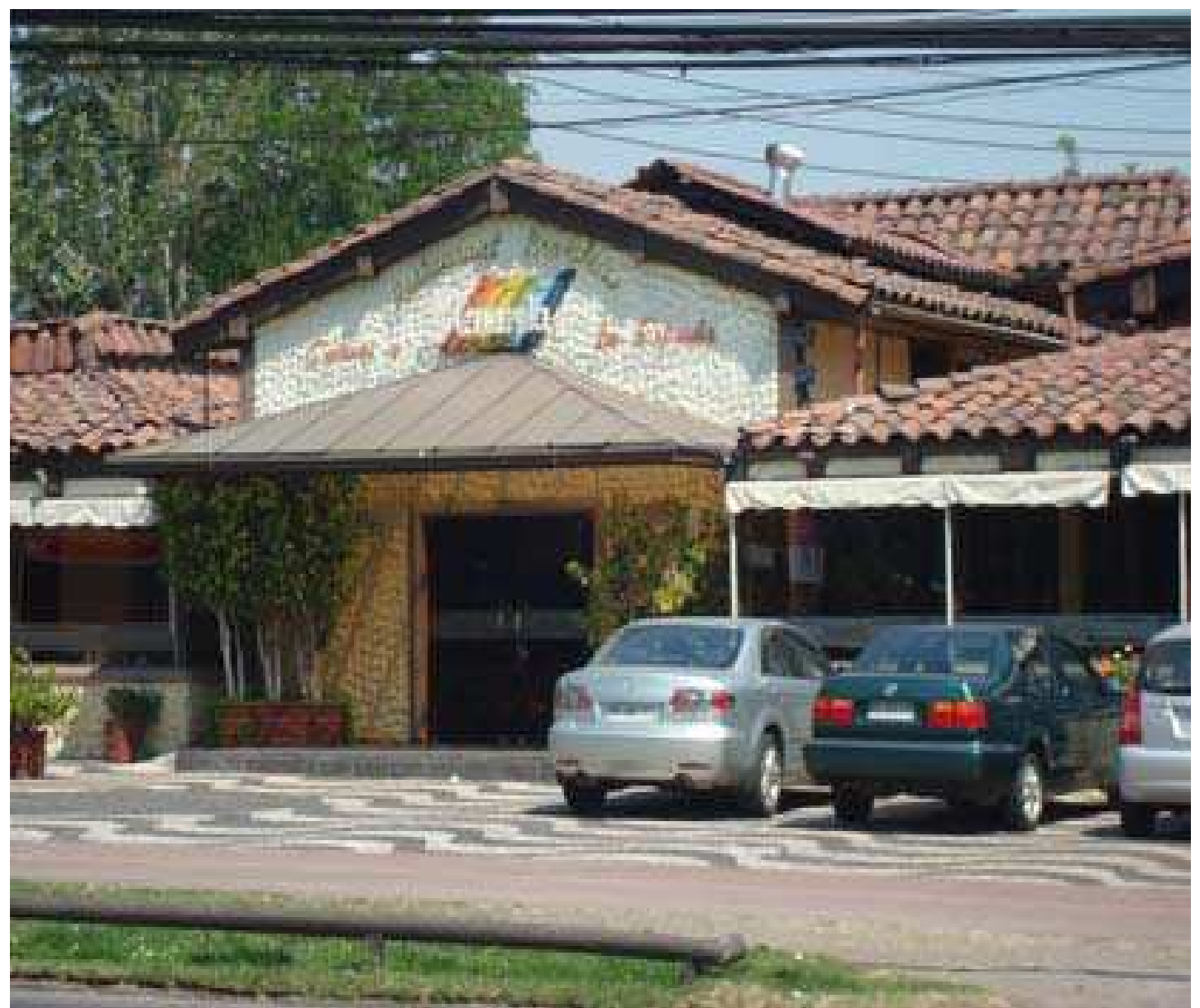

Fonte: Abrasel (2008) 
ANEXO D - Foto do Coquetel de frutas

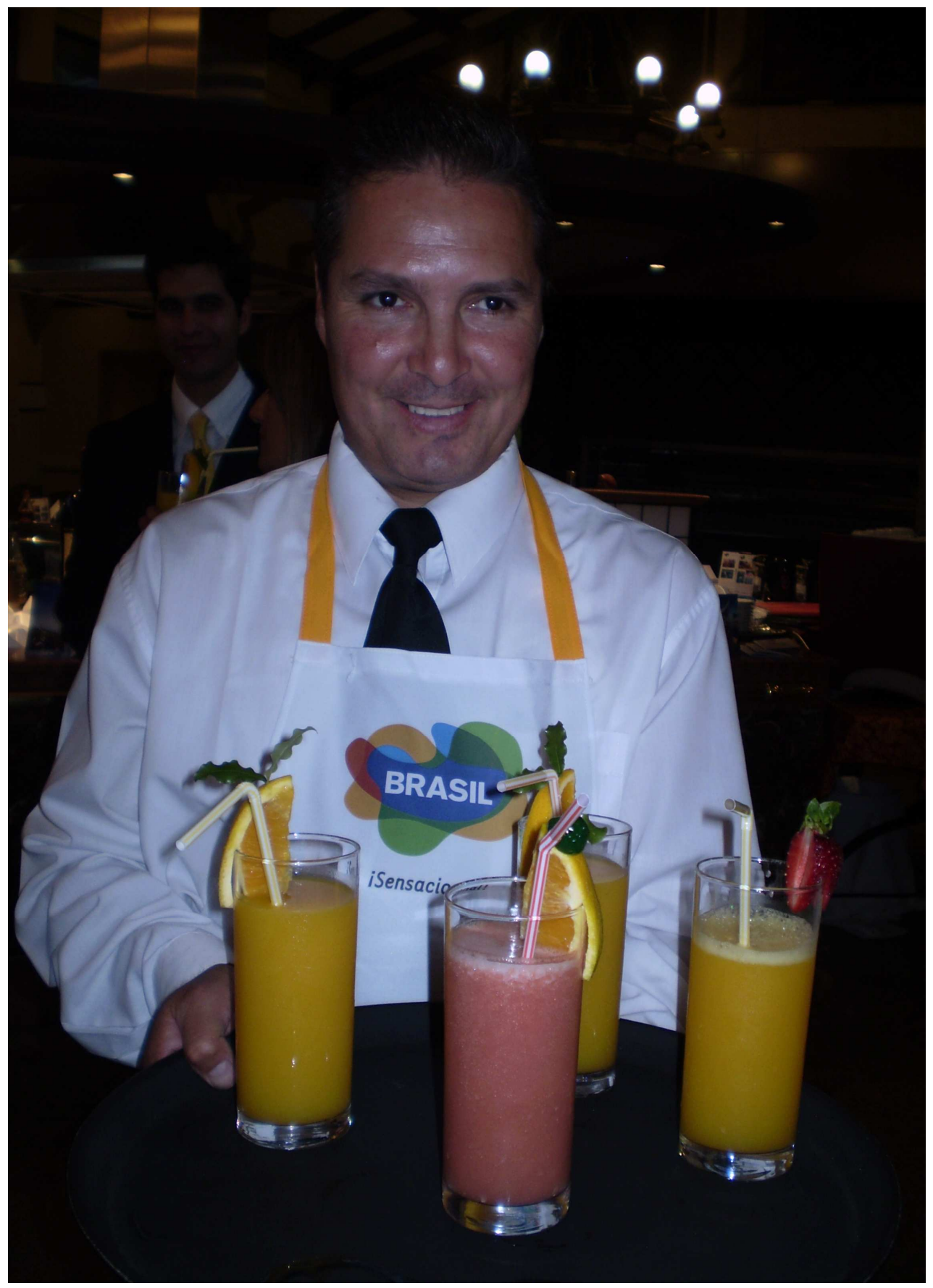

Fonte: Sara Agra 
ANEXO E - Foto do Prato de Entrada - Sopa fria de Palmito

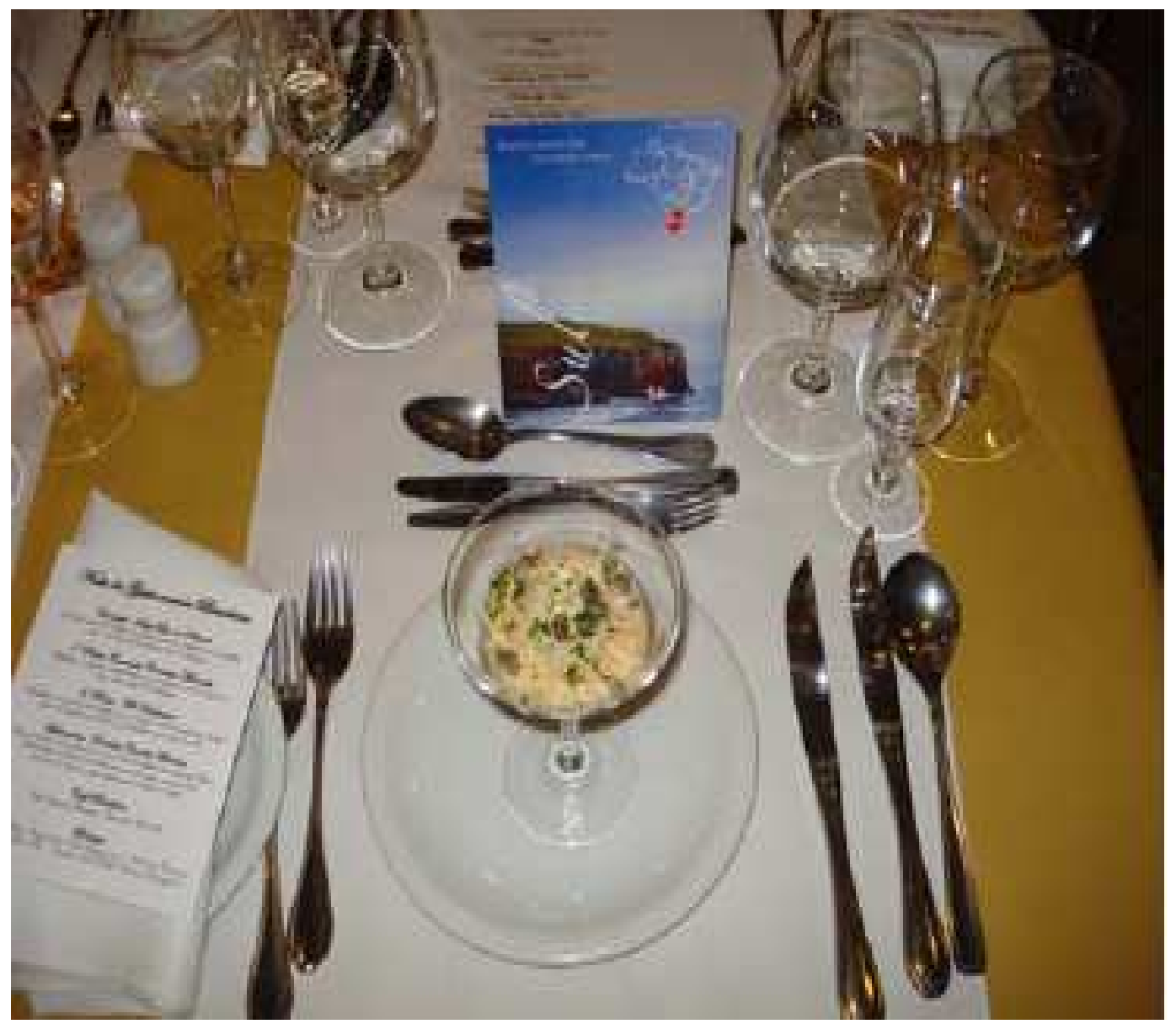

Fonte: Abrasel (2008) 
ANEXO F - Foto do $1^{\circ}$ Prato - Camarão ao molho de gengibre no abacaxi

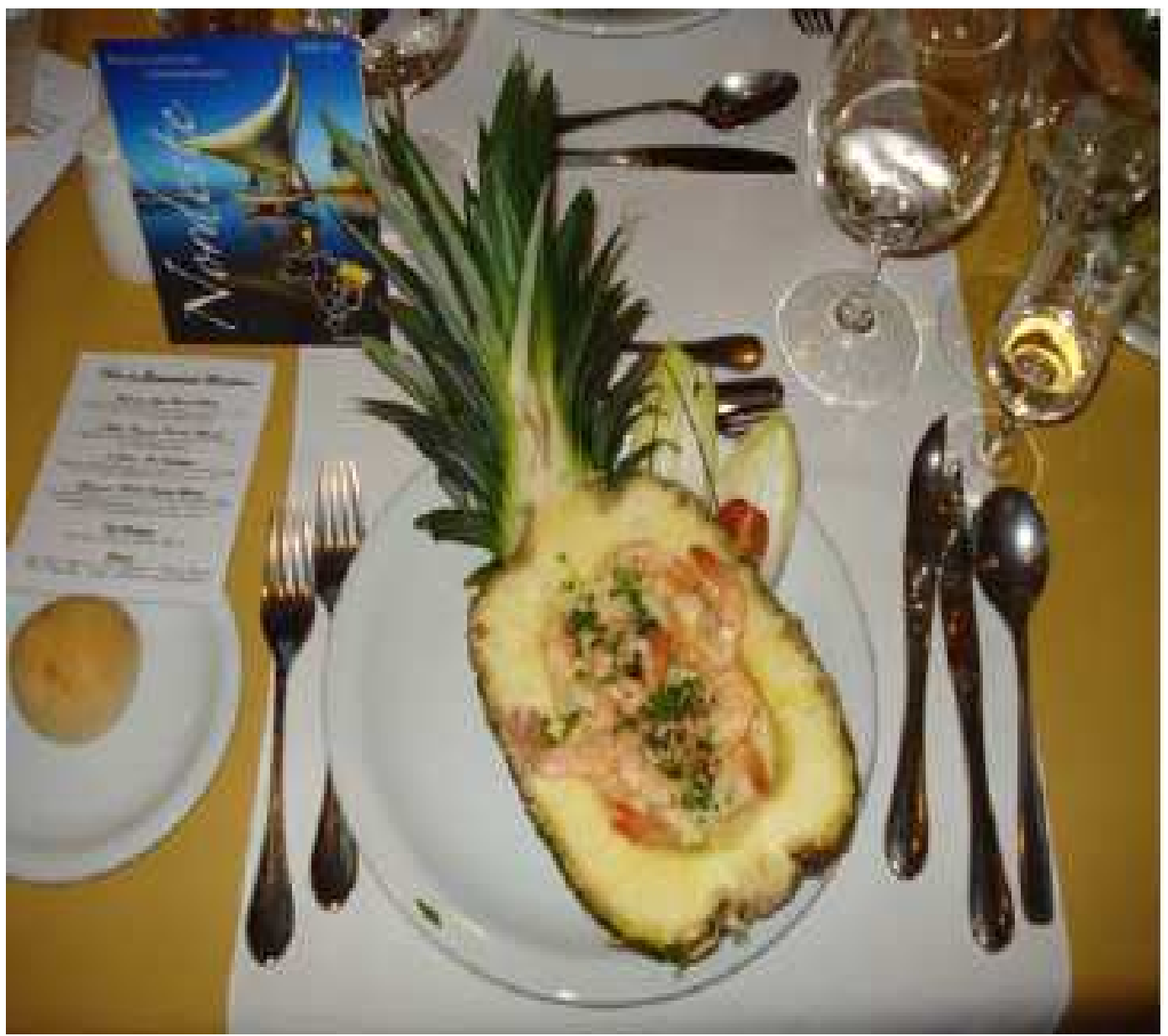

Fonte: Abrasel (2008) 
ANEXO G - Foto do Prato Principal - Filé ao molho de castanha de caju

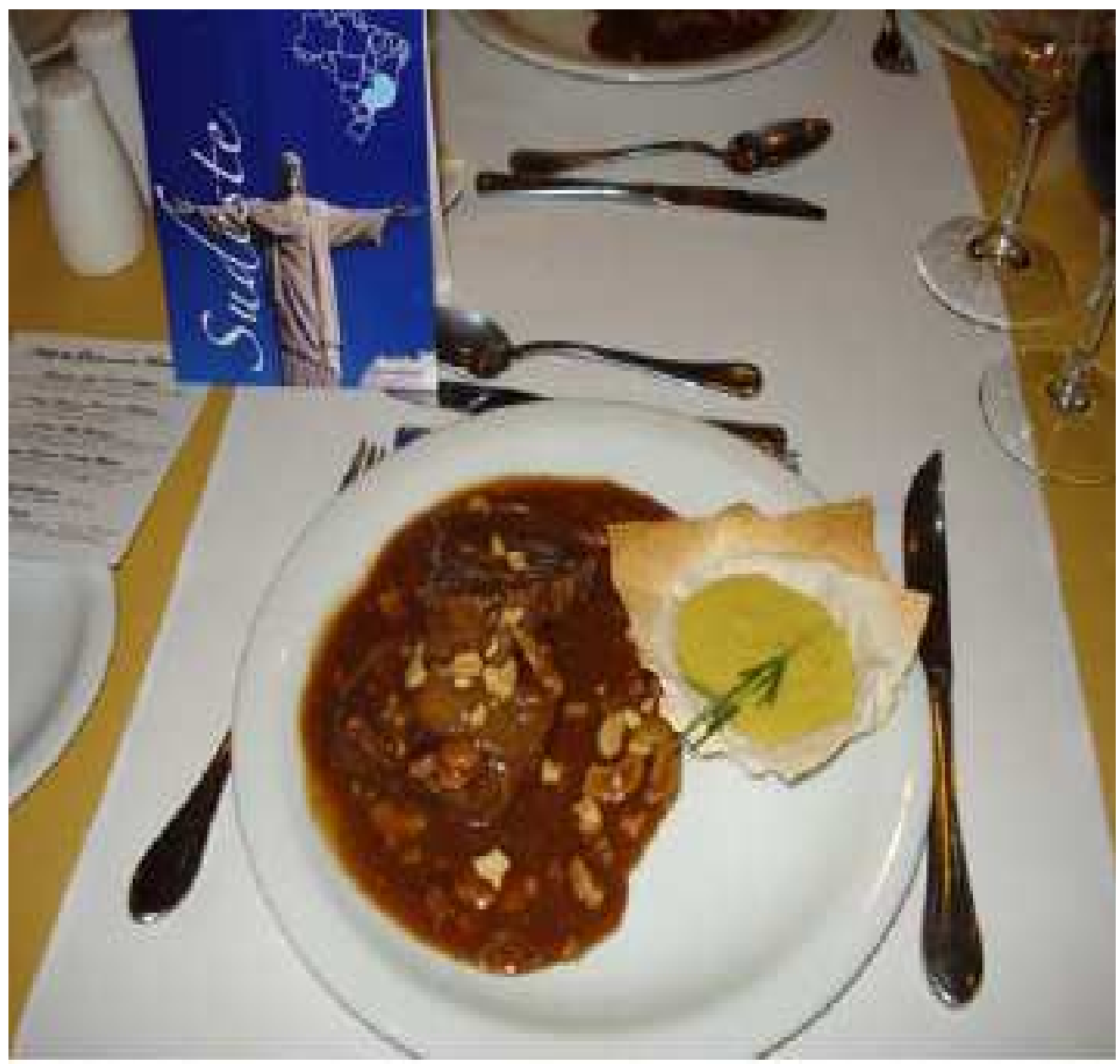

Fonte: Abrasel (2008) 
ANEXO H - Foto da Sobremesa - Cartola mineira

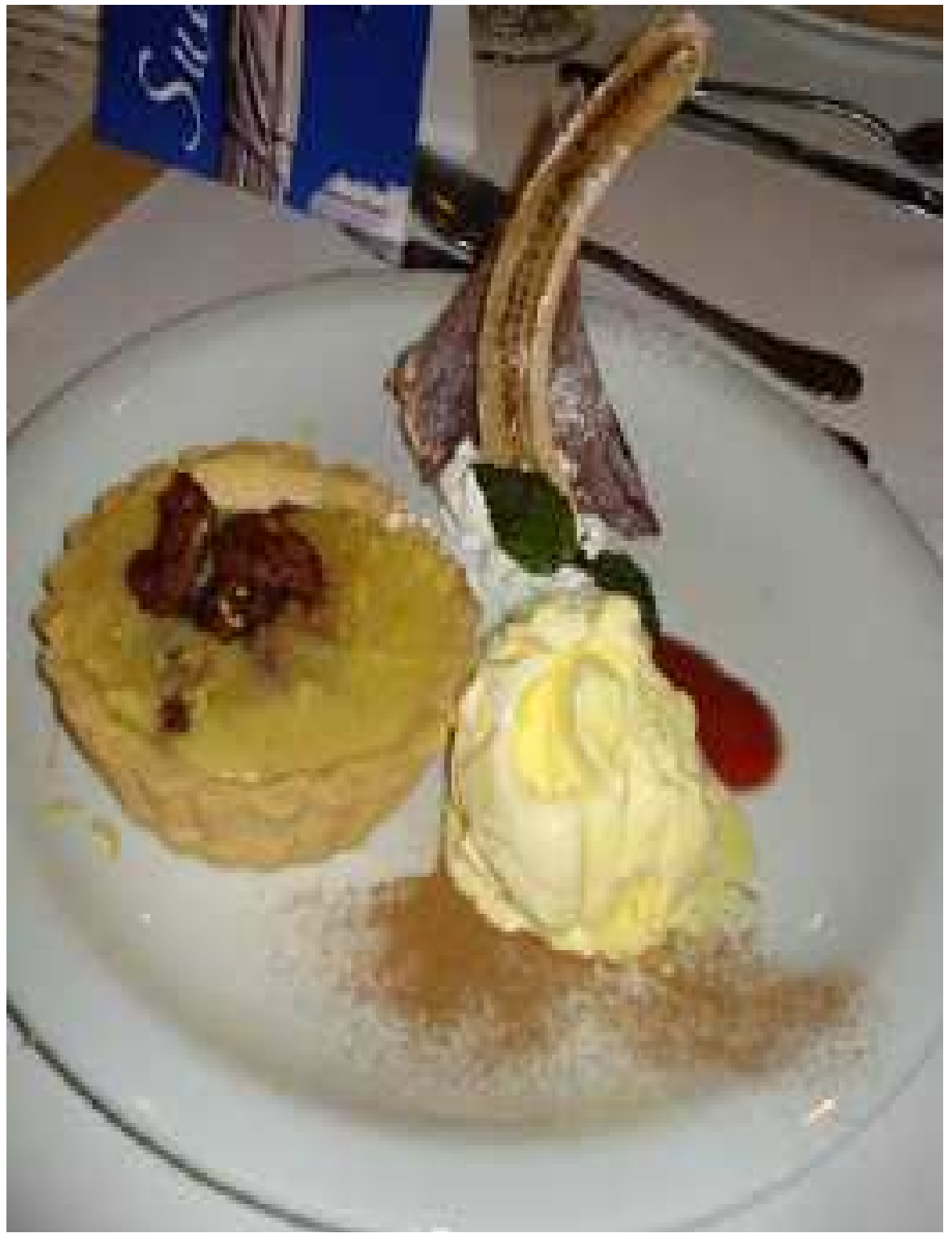

Fonte: Abrasel (2008) 
ANEXO I - Foto do Displey

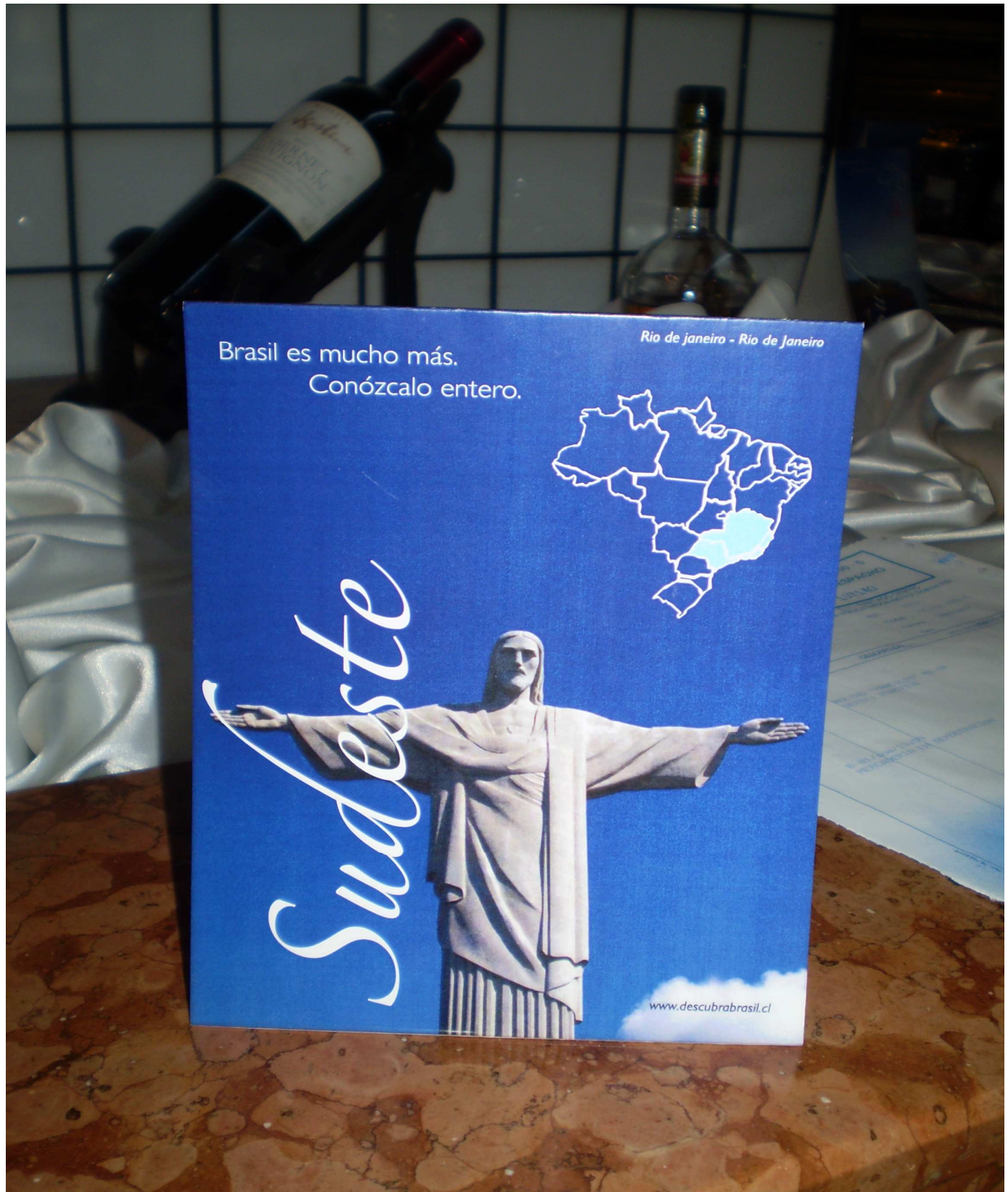

Fonte: Sara Agra 
ANEXO J - Foto do Brinde - avental

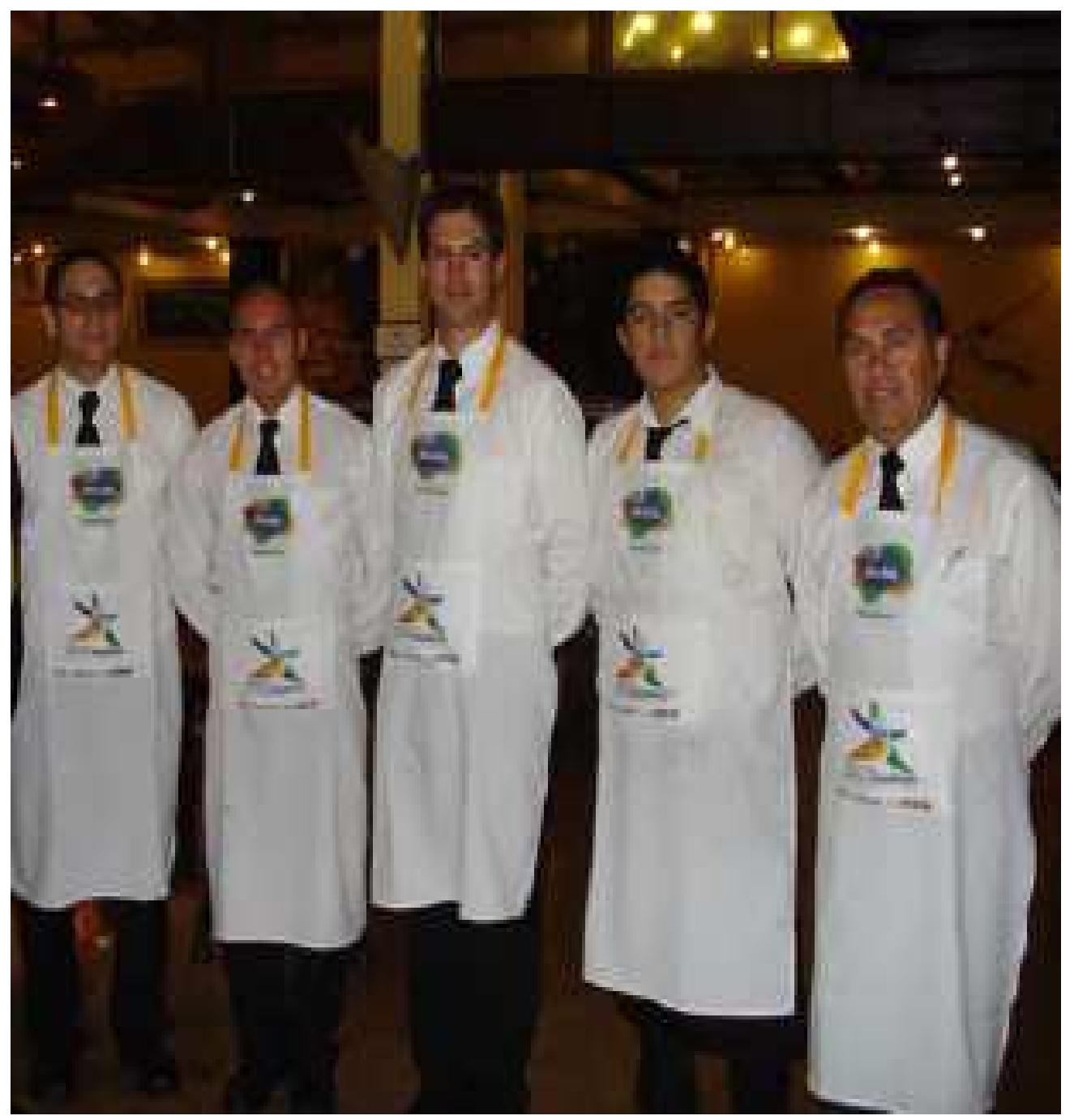

Fonte: Abrasel (2008) 
ANEXO K- Foto do Tótem

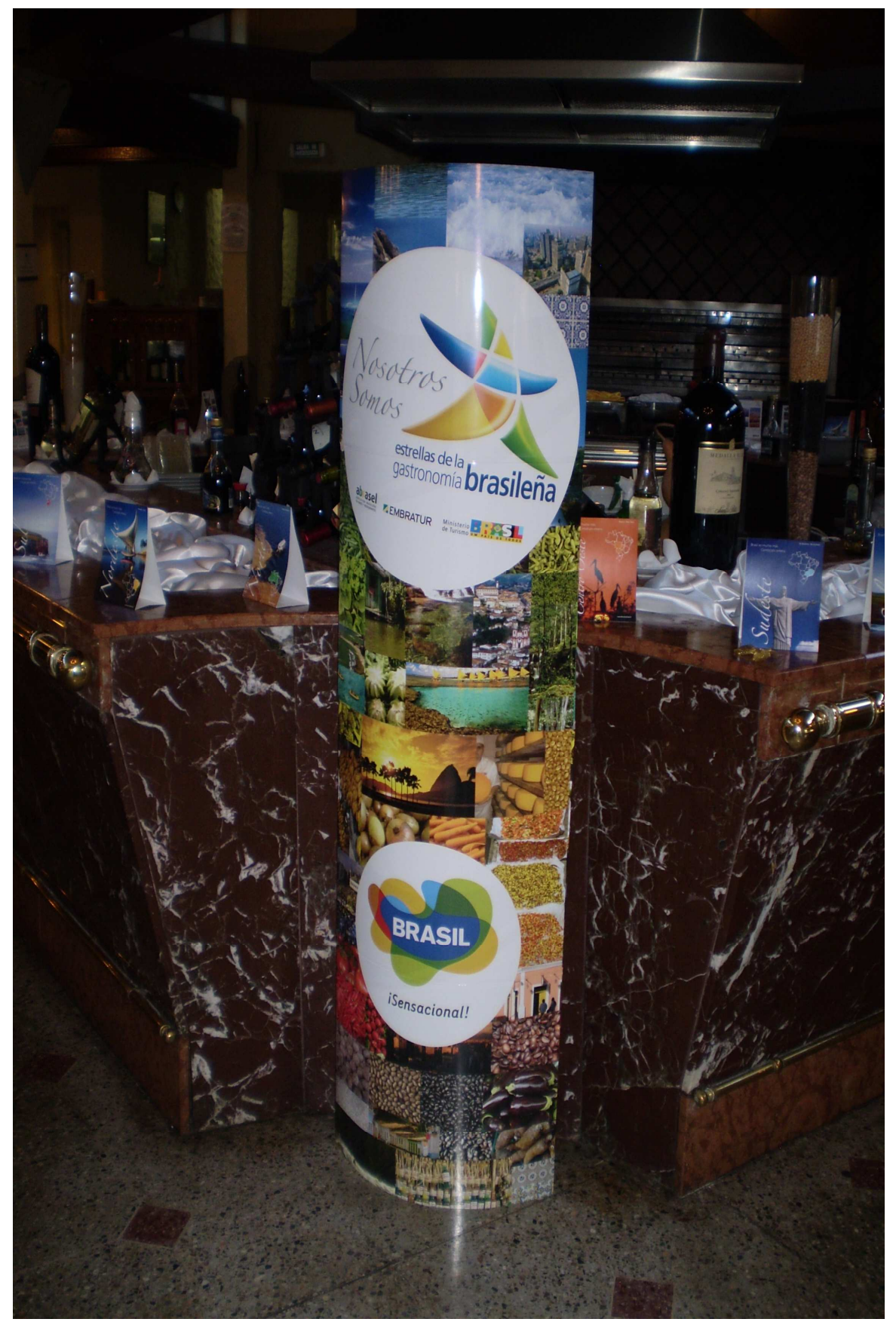

Fonte: Sara Agra 
ANEXO L - Foto do Guia - Roteiros do Brasil

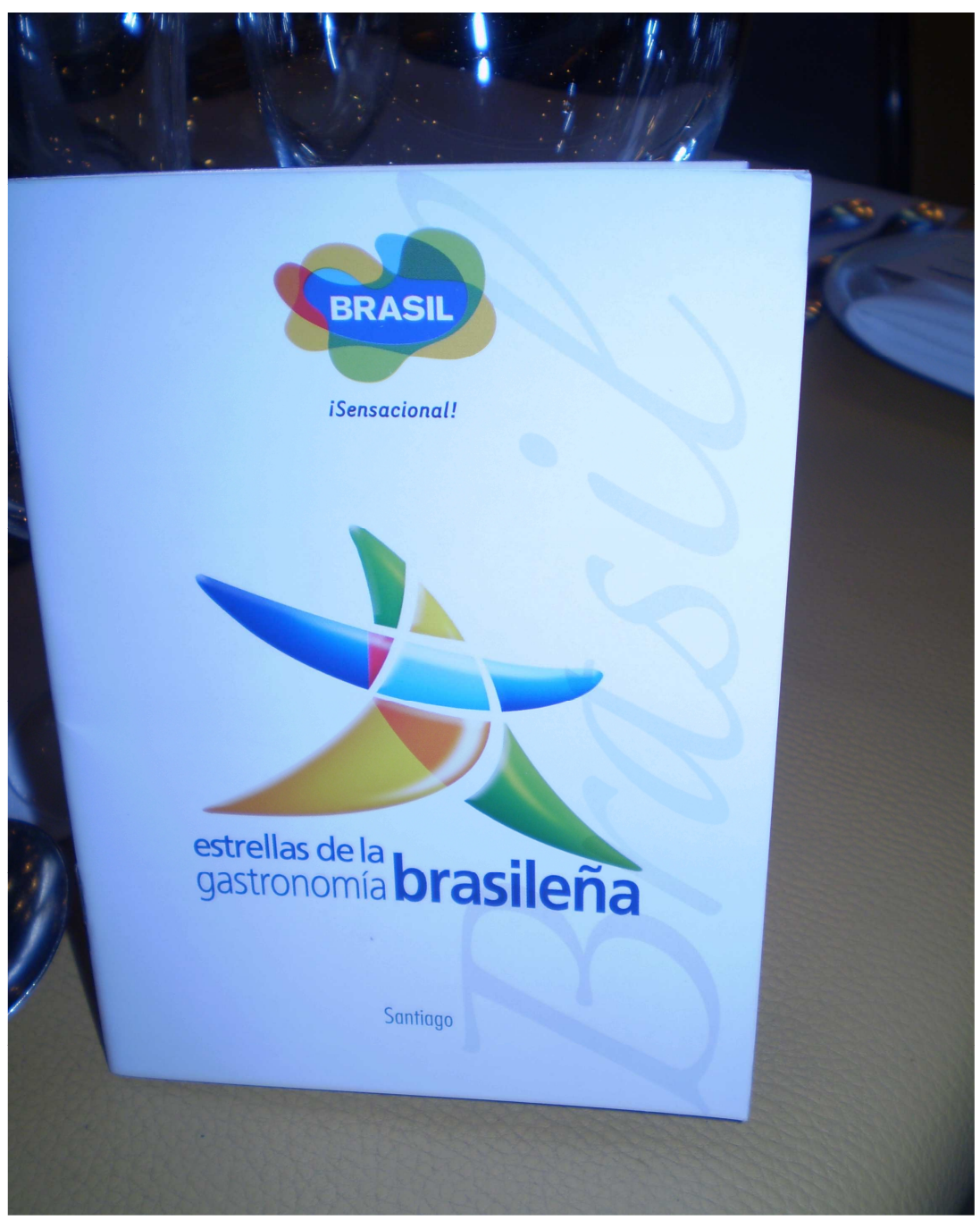

Fonte : Sara Agra 